CHAPTER 51

\title{
MODEL STUDIES OF THE DYNAMICS OF AN LSM MOORED IN WAVES
}

\author{
by \\ R. L. Wiegel, K. E. Beebe and R. A. Dilley \\ University of California \\ Berkeley, California
}

\begin{abstract}
Presented in this roport are the results of model tests performed 1 determine the motions of a moored LSM (Landing Ship Medium) and the associated mooring cable forces when subjected to the action of uniform periodic water waves. Dotails are given of the design and construction of the 1:80 scale model LSM and the dynamic balancing of the roodel. Pr ciples of the designs of the model mooring cables and of the meter for measuring the cable forces are also presented. The use of the laborato equipment, such as the wave-towing tank, the model basin, the photograp equipment, and the force and wave height meters are described, and the testing procedure is outlined. The data are presented in terms of the prototype in graphical form. Resonance conditions in the surging and heaving motions, and the associated high cable forces, are shown to exi for some initial cable tensions within the range of wave periods normal encountered in many ocean areas. The effect of a roll damping device $j$ shown.
\end{abstract}

\section{INTROUUCTION}

One type of mobile platform which has possibilities in the offshod oil program for core boring or well drilling operations is an existing suitably-modified vessel. Such a vossel must be moored within narrow limits or boring and drilling operations must be modified to allow for considerable oscillatory movements; probably the solution will be a co bination of both. The solution of the problem from a mathematical sta point is complicated by the fact that the mooring cables have non-line characteristics.

In order to work at sea it is necessary to moor a vessel so that will not drift under the action of wind, currents or the net motions associated with wave action. Further, it would simplify the operatior coring or drilling through a well in the ship if the oscillatory motic associated with waves could be minimized. In any case, the magnitudes these motions have to be determined. At the same time, the forces exe on the mooring cables have to be predicted. In addition, devices for damping any induced motions should be tested to rate their effectivene

A model of the dynamics of a moored LSM was made by the Wave Res! Laboratory, University of California, Berkeley, California, for the Ci ornia Research Corporation. 


\section{MODEL STUDIES OF THE DYNAMICS OF AN LSM \\ MOORED IN WAVES \\ MODEL LAWS}

Gravity, inertia, elastic, surface tension and viscous forces exist in a moored floating body system, neglecting compressibility effects. From a practical standpoint it is not possible to model the system in compliance with all modeling laws simultaneously. The vessel and the waves were modeled in accordance with Froude's modulus. The effect of Reynolds' modulus was neglected in the development of the model (however, turbulence existed in the flow) in conformity with standard naval architectural practice. The effect of surface tension was assumed to be of little importance as the model was to be made large enough that the waves would be well into the "gravity regime" and the cables were to be large enough that surface tension forces would not interfore with their motions.

The most serious question in a model of this sort is the neglecting of the offect of Reynolds' modulus (viscous forces). However, a brief analysis by Dr. Kitter (California Research Corporation, Ia Habra) indicated that the order of magnitude of viscous forces on the mooring cable would be small compared to gravity and inertia forces, and for the range of variables to be considered, the drag coefficient would be relatively insensitive to Reynolds number.

The following model laws were used in the dosign of the ship model, model mooring cable and the cable force meter:

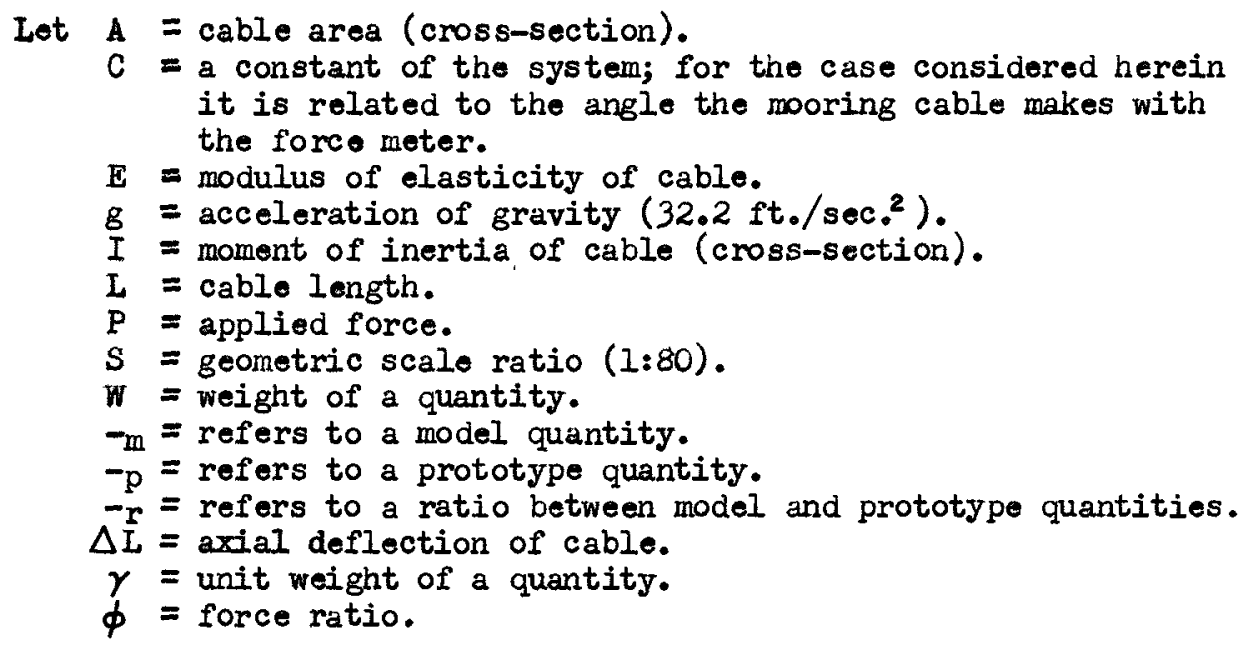

For Froude similitude, set the dimension of gravity force equal to the dimension of inertia, axial elastic and bending elastic forces, and obtain:

(1) Gravity forces

$$
\frac{\gamma_{m} L_{m}^{3}}{\gamma_{p} L_{p}^{3}}=\phi_{G}=\gamma_{r} L_{r}{ }^{3}
$$


(2) Inertia forces

also

$$
\begin{gathered}
\phi_{I}=\frac{\gamma_{m} L_{m}^{3} g L_{p} T_{m}^{2}}{\gamma_{p} L_{p}^{3} g L_{m} T_{p}^{2}}=\gamma_{r} T_{r}^{2} L_{r}^{2}=\phi_{G} \\
\gamma_{r} T_{r}^{2} L_{r}^{2}=\gamma_{r} L_{r}^{3}
\end{gathered}
$$

therefore

$$
\sqrt{L_{r}}=T_{r} \text {. }
$$

(3) Axial elongation forces in the cable

$$
\begin{aligned}
& \Delta L=\frac{P L}{A E} ; \quad A E=\frac{P}{\Delta L / L} ; \text { let } K=A E \\
& \frac{K_{m}}{K_{p}}=\phi_{A E}=\phi_{G}=y_{r} L_{r}^{3} ; \text { Let } A E=K, \text { then } K=\gamma_{r} L_{r}{ }^{3} .
\end{aligned}
$$

(4) Forces causing bending in the cable

$$
\begin{gathered}
\Delta=\frac{C P L^{3}}{E I}, \frac{P_{m}}{P_{p}}=\phi_{\theta}=\frac{\Delta_{m}(E I)_{m} L_{p}^{3}}{\Delta_{p}(E I)_{p} L_{m}^{3}}=\gamma_{r} L_{r}^{3}=\phi_{G} \\
\frac{\Delta_{m}}{\Delta_{p}}=L_{r}, \text { and }(E I)_{r}=\gamma_{r} L_{r}^{3} .
\end{gathered}
$$

These relationships will be reforred to in the following paragraphs on the design and construction of the ship model, the mooring cablo model and the nooring cable force meter.

\section{SHIP WODEL}

DESIGN

Before designing the ship model, it was necessary to choose a scale ratio that would satisfy three criteria:

1. The effects of surface tension would not be important.

2. The model would be small enough for use in the wave-towing tank, yet large enough that minor variations, when magnified to prototype, would not prove to be excessive.

3. The model would be large enough that a proper scale mooring system could be constructed and the expected mooring cablo forces would be of sufficient masnitude that they could be easily measured.

A scale ratio of $1: 80$ was chosen. The model was scaled from a U. Navy drawing (Buredu of Ships, ISir (1)-SO701-112485, ALT. and LSM (1)S0103-112380, ALT. 5), and from Califormia Research Corporation Drawing (Nos. LC7990-7999, 9000-9007). Transverse cross section drawings for a stations along the ship were prepared to assure accurate ship dimensior (Figure 1). The superstmucture, except for the foreward superstructure deck, was left off the model, as were the several decks, and the model was designed to built to its own freeboard. It wus necessury to appro: mate successively sections $C \sim C$ from station $U$ on, as dratings for thes sections were unavailable. For the region near the bow where the shap changes considerably, many cross sections were drawn. The skegs and 


\section{MODEL STUDIES OF THE DYNAMICS OF AN LSM MOORED IN WAVES}

rudders were drawn up soparately, since they were left off the bisic model shell. Because the model hull form wis to built up in the manner shown in Figure 1, a series of drawings were prepared of horizontal cross sections through the model at 3/4-inch intervals above the bottom tangent.

The weight of the completely balanced model was to be 3.78 pounds while the model shell was designed to weigh 1.20 pounds, leaving 2.58 pounds to be added for static and dynamic baldncing.

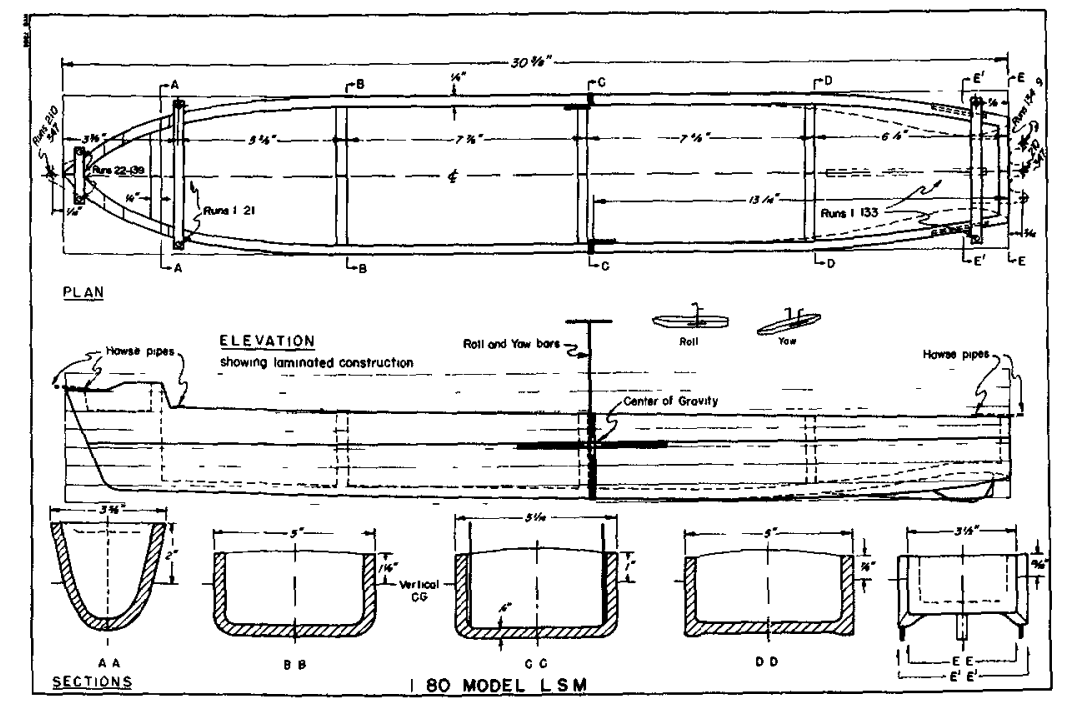

Figure 1 .

\section{COISTRULTION}

The model LSU was constructed of clear soft pine. The wood was planed smooth to a $3 / 4$-inch thickness. Then individual horizontal cross sections (at vertical distance $3 / 4$ inch below each water line plane) were scaled off the drawings and a section of pine was cut to approximate this water plane area. The sections were glued together to make a rough hull form which was finished to the outside dimensions of the ship and to a 1/4-inch wall thickness. Bulkheads were added to approximately the quarter points of the hull to five the model strength to resiste the lateral forces which were likely to be encountered in handling. The wodel was then covered with several coats of spar varnish.

The points of attachment of the moorine cables (through bars) are shown in Figure 1. Originally these bars were extended completely across the ship model in order to guard against failure of the side wall of the model due to excessive mooring cable lodds. However, after the f'irst series, this system was nodified as shown, eventually leading to centerline mooring both bow and stern. 


\section{COASTAL ENGINEERING}

\section{BAIANCING}

After the basic model shell was completed, weights were added to bring the model up to its correct scale weight. These weights were place in such a manner that the center of gravity of the model was properly located, and so that the natural periods of roll and pitch would be correct This static and dynamic balancing was performed as follows: The modol wa suspended fore and aft by suspension bars as shown in Figure 2a. The weight of the foreward suspension was counterbalanced on the scale prior to placing the model on the scale. Since the distances from the aft suspension bar to the center of gravity, from the aft suspension to the fore ward suspension bar, and the total weight of the model were known, it was possible to calculate the weight needed to balance the model when the longitudinal center of gravity was correctly positioned; this was done by taking moments about the aft suspension bar. Smill pieces of load wero used as weights for adjusting the balance.

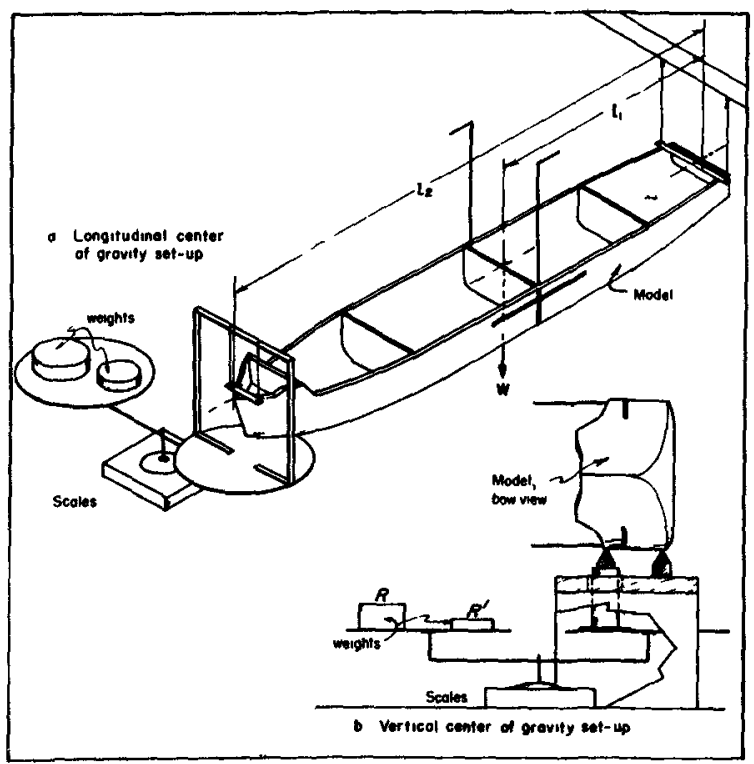

Figure 2. Buldancing proceedure.

The model was placed on the device illustrated in Figure $2 \mathrm{~b}$ and moments were taken about a given point (varied for each trial to ninimize the effects of human error) and tho necossary weight was calculated and set on the scale. The movable weights then were a justed until the vertical center of gravity was prope located; this was corpleted after about twenty trials. After locating the vertical center of gravity the perio of roll was adjusted.

The model was placed in the model basin, inclined and released. The natural period of roll was observec and recorded. The transverse position of the cente of gravity was obtained by ddjusting woights until sel

list was observed. Then lead weights were moved in a direction paralle] to the axis of pitch, until the correct period of roll was obtained. B? noving the weights parallel to the axis of pitch, the weights remained: the same position with respect to the vertical, so that the vertical cel ter of gravity was unchanged. A few trials with the dovice used to loc: the vertical center of gravity confirmed the fact that the vertical cent of gravity had not shifted.

The last step in the dynamic balancing of the model was the adjust. ment of the period of pitch. The experimental method used is illustrat in Figure 3, and the calculations required for this method are presente 


\section{MODEL STUDIES OF THE DYNAMICS OF AN LSM \\ MOORED IN WAVES}

below. The period of pitch of a vessel is proportional to the radius of gyration of the vessel in the pitchung direction, and is given by the oulation (Rossell and Chapman, 1939)

$$
\mathrm{T}_{\mathrm{n}}=\frac{1.108 \mathrm{~K}_{1}}{\sqrt{\mathrm{GM}}}
$$

where $\mathrm{T}_{n}=$ natural period of pitch,

$\mathrm{K}_{1}=$ radius of gyration of the model,

$G M=$ longitudinal metacentric height of the model, and

$1.108=2 \pi / \sqrt{g}\left(\right.$ wher $\left.g=32.2 \mathrm{ft} / \mathrm{sec}^{2}\right)$.

Severe damping of the pitching motion of the structure precluded accurate direct measurement of the period of pitch so that it was necessary to determine the radius of gyration of the model about the pitching axis by using the bifilar pendulum method as given by Timoshenko (1937). By hanging the model as shown in Figuro 3, it can bo shown that the period of oscillation of the bifilar penculum so set up is a function of the radius of gyration of the vossel about tho yaw axis. In addition, the

Ficure 3. Bifilar pendulum setup.

radius of gyration about the yaw axis, and the radius of gyration about the pitch axis ar ossentially equal (personal communication, Dr. A. D. K. Laird, University of California, Berkeley). From Timoshenko (1937) it can be shown that

$$
\mathrm{T}_{\mathrm{p}}=\frac{2 \pi \mathrm{K}}{\mathrm{a}} \sqrt{\frac{1}{8}}
$$

where $T_{p}=$ natural period of oscillation of suspended model in air,

$I=$ length of suspending lines, and

a = equal distance from CG to suspending lines.

In the experimental adjustment of the period of pitch $1=7.125$ feet, $a=1.0625$ foet, $g=32.2 \mathrm{ft} . / \mathrm{sec}^{2}$, and $k_{1}=63.4$ feet $/ 80=0.792$ foot. Substituting these values in Lquation 6, it was found that the period of the pendulum would have to be 2.2 seconds for the radius of gyration in the pitching direction to be properly located. The weights in the model were then adjusted until this period of the pendulum was obtained. The Iongitudinal metacentric height wes adjusted by other moans.

Following this final adjustment of the weights, the complete balancing procedure was repeated, and the model was found to be balanced, and 


\section{COASTAL ENGINEERING}

thus both geometrically and dynamically similar to the prototype, within the linits discussed in the introductory remarks.

\section{MOORIVG CABLAt WUDHL}

Inspection of the model relationships previously derived indicates that for geometric similarity the diameter of the rodel cable must be scaled according to the relationship

$$
\mathrm{d}_{m}=\frac{\mathrm{d}_{\mathrm{p}}}{80}
$$

In the same unit weight properties are to be maintained, it is necessary to scale the cable according to the relationship

$$
d_{m}=\frac{d_{p}}{(80)(b)}
$$

where $b>1$ since the cable is stranded and the resulting unit weight for a given diameter is less than that of a solid wire. If the axial deflection forces of the mooring system are to be maintained in scale, $t$ diameter of the mooring cable must scale according to the rule

$$
\begin{aligned}
(A E)_{r} & =\gamma_{r} L_{r}^{2}, \text { but } E_{r}=\frac{\text { elastic modulus of nodel }}{\text { lastic modulus of prototype }} \\
& =\frac{3 \times 10^{7}}{10^{7}}=3 \\
(A E)_{r} & =3 d_{r}^{2}=\gamma_{r} L_{r}^{3} ; \quad \therefore d_{r}=\sqrt{\frac{Y_{r}}{3}} L_{r}^{3 / 2} .
\end{aligned}
$$

If the bending properties of the cable are to be in scale, it is necessary to scale the bending resistance of the cable cross section accordi to the relationship

$$
\text { (EI) } r=\gamma_{r} L_{r}^{5} \text { or } \quad d_{r}^{4}=\gamma_{r} L_{r}{ }^{5}
$$

or

It was not possible to satisfy the four model criteria by choosing a proper cable diameter. Therefore, the cable diameter was chosen so $t$ the moment of inertia of the section would correspond to and be in scai with that of the prototype stranded cable. This meant it was necessar: choose a diameter somewhat smaller than the outside diameter of the pre type stranded cable, since a geometric scale mould mean that the model 


\section{MODEL STUDIES OF THE DYNAMICS OF AN LSM MOORED IN WAVES}

cable extrapolated to prototype conditions would correspond to a steel rod in bending stiffness. Split lead shot were added to the mooring cable at one-inch intervals to bring the cable up to the proper weight requirements. An arbitrary spacing of 1 inch between shot having been assumed, the required shot diameter was 0.050 inch, which was readily available. The axial deflection characteristics of the cable were calculated and found to be less than those required; hence, some axial flexibility of the cable system was built into the force meters. This kept the total mooring system deflection in scale. The only criteria not satisfied was that of geometric scale of the diameter, which would result in the viscous drag and inertia forces being even more out of scale. However, as was assumed in the case of the ship model, these forces would be small compared to other forces acting on the cable.

\section{FORCA MERER}

The force meter served two purposes: it was used as a sensing element in a force recording system, and it was used in the modeled mooring system to satisfy scale factor requirements for cable elongation due to axial loads. In designing the meter it was necessary to satisfy the similitude requirements for cable deflection (as determined from model laws) and to insure sufficient sensitivity so that the meter could measure the smallest expected forces.

In order to provide the proper deflection sharacteristics it was necessary to use other than a simple structural shape (Figure 4 ). The deflection characteristics of the beam used were calculated through

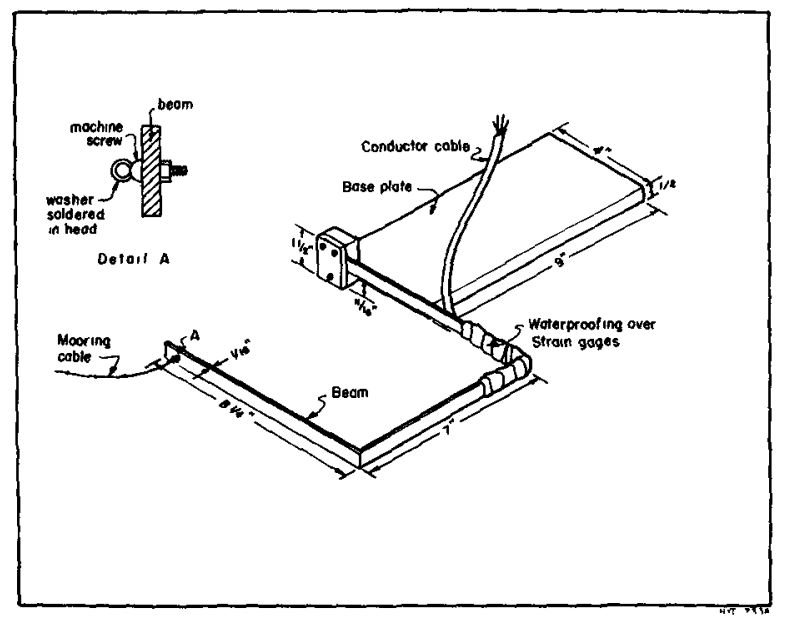

Figure 4. Force neter included as they have been published elsehwere (Beebe, 1956). application of the principles of virtual work. The force measuring system was designed to provide maximum possible recorder sensitivity to applied cuble force. Strain gages were used for the force measuring elements; force was measured indirectly by measuring the strains induced in the meter beam by bending moments caused by the force in the mooring cable. The strain measure ments were recorded with a Erush IIectronic Company recordins system.

Details of the force meter design, construction and calibration will not be 


\section{COASTAL ENGINEERING}

\section{GENERAL CONSIDERATIUNS}

The motion of a freely-floating vessel in a seeway is extremely complex. Studies have been made in the past (Froude, 1861; Kriloff, 1898 of the motion of rolling and pitching of such vessels. Heaving has been studied by Haskin (1946). Other investigators have studied these proble recent summaries have been given by ireinblum and St. Uenis (1950) and weinblum (1955). They present equations and graphs of various snip moti functions, among which are the magnification (response) factors (for the various degrees of freedom) which are shown to be functions of the ratio of the wave period to the natural period of the vessel, and the exciting

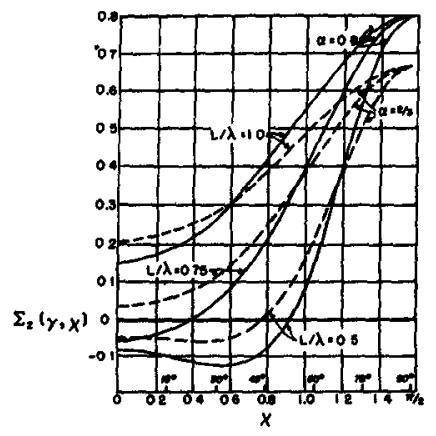

- Heaving force function $\Sigma_{z}(y, x)$ for two wail-sided vessels plotted agoinat heading angle $x$ with $L / \lambda$ as parameter Waterlino coetficient $a=2 / 3$ and 08

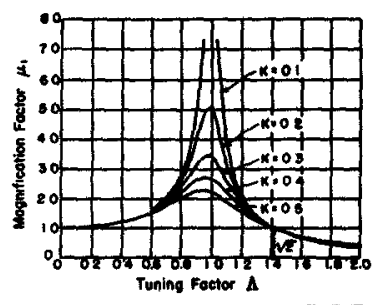

D Mognification foctor $\mu_{1}=\frac{\sqrt{1+k^{3} K}}{\sqrt{\left(1-A^{2}\right)^{2}+\alpha^{2} A^{2}}}$

mom minum est oun

Figure 5. factors which are shown to be functions of the ratio of the wave length to the ship length (see Figure 5 for example). Both of these sets of factors are, of course, dependent upon several other war and vessel characteristics. The author: state that little is known of the surge: sway and yaw motions of floating vessel: and that knowledge of the total motion of a vessel, including phase relationships between the various motions, is a most nil, although it is known that cer tain couplings between the motions in $t$ different degrees of freedom exist. of particular irportance to studies of moo ing problems are the possibilities of induced roll, sway and yaw even when th vessel is encountering only head seas (Grim, 1952).

The above-mentioned studies were concerned with periodic waves of unifor amplitude. Hecently, a few studies of ship motion in non-uniform waves have been published (S't. Denis and Pierson, 1953; Fuchs, 1955; Sibul, 1955).

The details of ship notion are beyond the scope of this report and th reader is refierred especially to the paper by veinblum and St. Denis (1950) for the necessary background.

In consiclering a moored vessel the problem becomes wore complicat especially as the elastic restraining force (the mooring system) is no linear. The motions of surge, sway and yaw become of prime importance

It appears that only a few studies have been made of the notion $c$ a moored vessel (..ilson, 1950; Carr, lucGraw and Snapiro, 1953; Beebe, $1955 \mathrm{a}, \mathrm{b}$; O'Brien, 1955; iilson and sbramson, 1955). These studies, v the exception of Beebe's, are of a greatly simplified problem, prinari that of the longitudinal motion of a vessel moored alongside a pier, $t$ 


\section{MODEL STUDIES OF THE DYNAMICS OF AN LSM MOORED IN WAVES}

motion being induced by relatively long period harbor seiches of small amplitude. Nll notions excepting surging are neglected, although ,ilson (1950) comented upon the transverse motion.

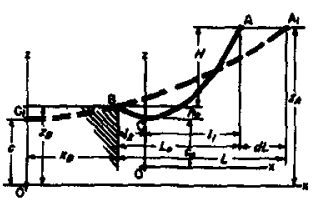

Fig. 6. Teonetry of mooring rope sus pansion.

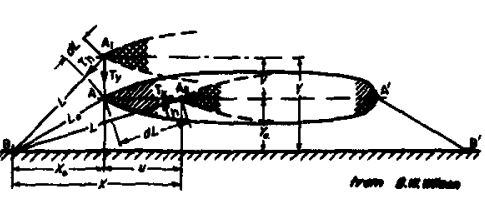

Fig. 7. Geometry of longitudinal and transverse ship motion.
The pioneering effort on the mooring problem was inade by wilson (1950). The generalized seometry of the dockside mooring rope suspension is shown in Figures 6 and 7. ileferring to Figure 6 for an explanation of the symbols (where in the generalized case the

lowest point of cable sag is at $C_{1}$ which is outside of $A_{1} B$ ) the equations of the catenary were given as

$$
\begin{aligned}
& z=c \cosh \left(\frac{x}{c}\right) \\
& s=c \sinh \left(\frac{x}{c}\right)
\end{aligned}
$$

where $s$ is the length of the hypothetical cable from point $c_{1}$ to any point $(x, z)$ on the catenary. Further

$$
\begin{aligned}
z_{B}+H & =c \cosh \frac{x_{B}+L}{c} \\
z_{B} & =c \cosh \frac{x_{B}}{c}
\end{aligned}
$$

ana thus

$$
\begin{aligned}
& \mathrm{H}=c\left(\cosh \frac{x_{B}+L}{c}-\cosh \frac{x_{B}}{c}\right) \\
& S=c\left(\sinh \frac{x_{B}+L}{c}-\sinh \frac{x_{B}}{c}\right) .
\end{aligned}
$$

after certain simplifications were l.ade, wilson (1950) gave the horizontal component of rope tension $\mathfrak{T}_{h}$, at points $A_{1}$ and $B$ ds

$$
T_{h}=\frac{w_{c} L^{2}}{\sqrt{12\left[S^{2}-\left(H^{2}+L^{2}\right)\right]}}
$$

where $W_{c}$ is the weight per unit length of the cable.

The next step taken by filson (1950) was to deternine the relationships between cable tension and elongation for several types and sizes of standard mooring cables (coir rope and steel wire rope). In order to tilize these data, a further simplification was nade wherein it was 


\section{COASTAL ENGINEERING}

shown that for common dockside mooring the following equation was of sufficient accuracy

$$
I=\sqrt{S^{2}-H^{2}}
$$

Utilizing this approximation, and referring to Figure 7 for an explanatic of the symbols, the relationship between the components of cable tension and the components of ship movements were developed. These relationship: are shown in Figure 8. Also shown in Figure 8 are the best-fit expenent: curves, which are of the form

$$
\mathrm{T}_{\mathrm{X}}, \mathrm{y}=\mathrm{k}(\mathrm{u} \text { or } \mathrm{v})^{n}
$$

where $\mathrm{k}$ is a constant and $\mathrm{n}$ is a numerical exponent. For the case 0 a ship with many mooring lines, this was expressed for the longitudinal directions as

$$
\sum r_{x}=c u^{n}
$$

where $\mathrm{C}$ is a constant which depends upon the number, size and conditio of the cables and $n$ depends upon the tension in the cables.

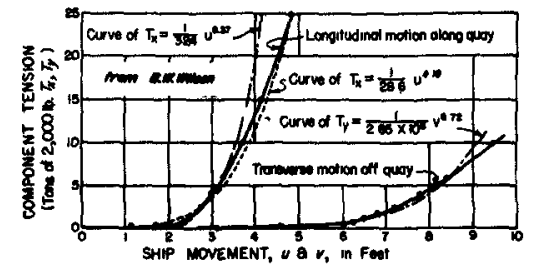

Figure 8. Relationship between rope tension and ship movement.
A harbor seiche has a relatively long period (usually in the range of a minute or more - sometimes much longe and usually has a low amplitude. It i possible to describe the water particl velocities and accelerations rather simply compared with the case of seas and swell. These approximations were used by vilson (1950), together with : approximation by Havelock (1940) which expresses the wave force on a rigid vessel which extends to the bottom.

is not necessary here to go through the various steps, but merely to present the final result

$$
\frac{d^{2} u}{d t^{2}}+\frac{K}{2 M} \cdot \frac{d u}{d t}+\frac{C}{2 M} u^{n}=\frac{K V}{2 M} \cos p t-\frac{V p}{2} \sin p t
$$

where $K$ is a constant which depends essentially upon the size and sha of the vessel, $\mathbb{I}$ is the mass of the ship and $p$ is the angular frequency of the surge. $V$ is given by

$$
\mathrm{V}=\frac{\mathrm{Ap}}{\mathrm{qd}} \sin \mathrm{q} \mathrm{x}
$$

where $A$ is the seiche amplitude, $q$ is the nodal frequency of the seiche, and $d$ is the water depth. It should be noted that the phase angle has been neglected and the damping is shown as being proportiona] to the first power of the velocity rather than the square of the veloci 


\section{MODEL STUDIES OF THE DYNAMICS OF AN LSM MOORED IN WAVES}

The natural frequency of the system thus depends upon the amplitude of the forcing function as well as upon the spring and mass characteristics of the system.

After certain other simplifications were made, Vilson (1950) showed the relationships between resonant period of ship oscillation, $\tau$, and maximum individual cable tension, $T_{x}$, versus seiche amplitudes, $A$,

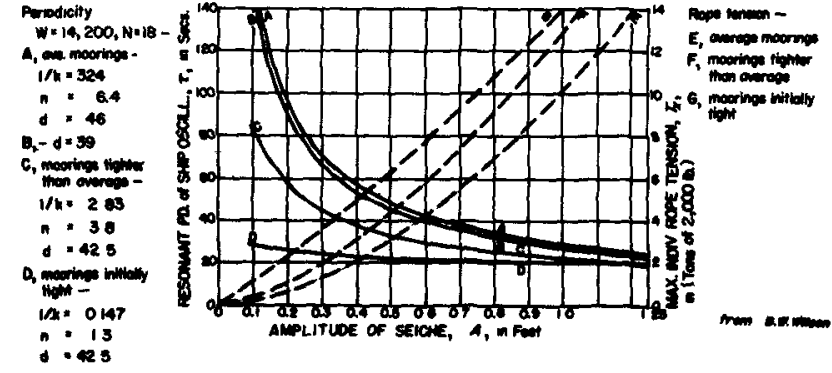

Figure 9. Influence of rope tightness on the resonance in longitudinal ship motion. for several conditions of cable tension (Figure 9). The effect of cable tension on the periodicity of the system is apparent: the higher the tension the lower the resonant period. The effect of amplitude is relatively unimportant for cables with high tension, but very important for cables with low tension: the greater the seiche amplitude the lower the resonant period of the system.

Recently Equation 18 has been treated by ilison and Abramson (1955) using the Ritz method (which is useful for certain non-linear differential equations). Typical results are shown in Figures 10 and 11 . In Figure 10 is shown the relationship between the maximum amplitude of horizontal ship displacement, $u$, and $\eta^{2}$ for various values of seiche amplitude. $\eta$ is

$$
\eta=\frac{p}{\omega}
$$

where $p$ is the angular frequency of the seiche. $\omega$ may be considered as the non-linear equivalent of the natural frequency

$$
\omega^{2}=\frac{C}{2 M}=\frac{N k}{4 M}
$$

although the non-linearity, entering through $k$ results in a departure from the ordinary dimensions of frequency.

The above information on mooring has been presented although it is a great simplification compared with the problem of the LSW moored at sea. It does point to the great inportance of initial cable tension and to the possible importance of wave amplitude. 


\section{COASTAL ENGINEERING}

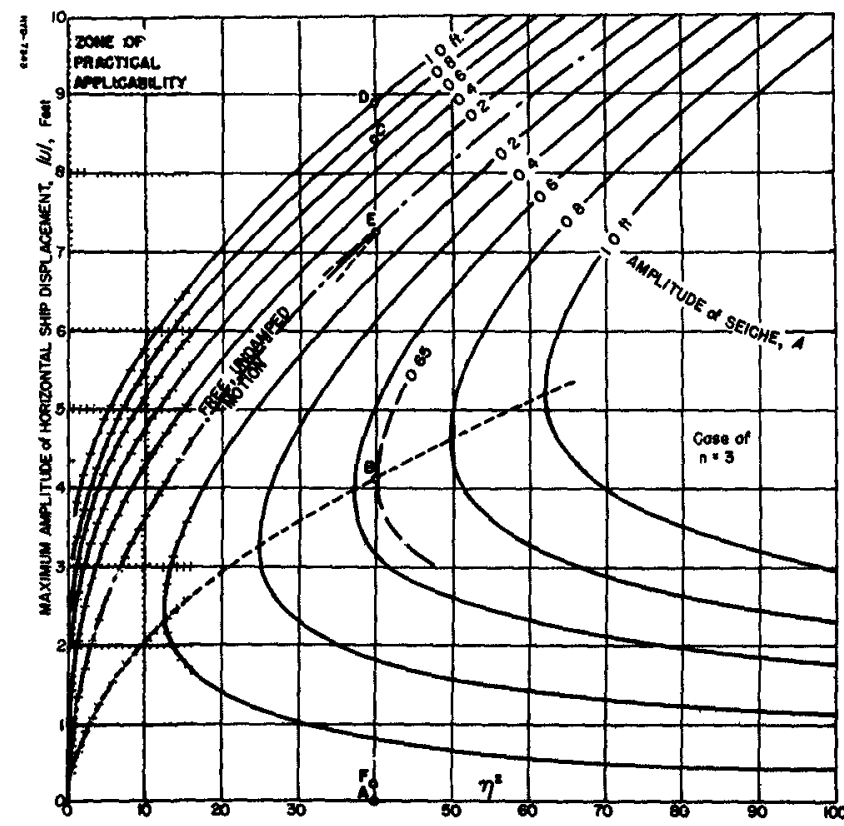

Figure 10. Typical response curves of longitudinal ship displacement

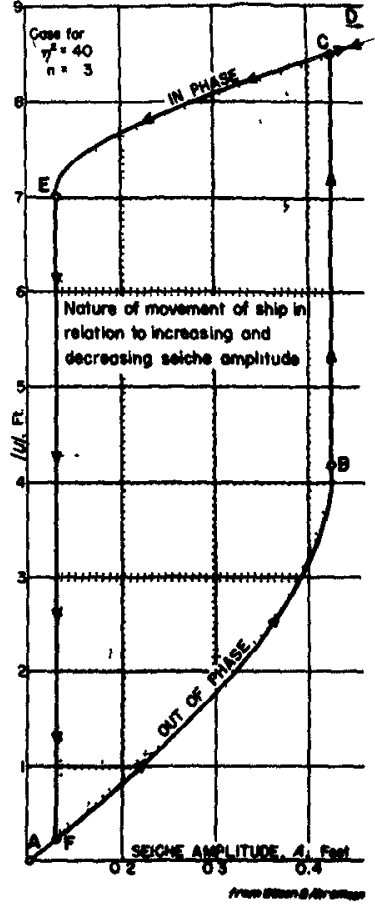

Figure 1 .

\section{LABORATORY EQUIPMENTI}

The laboratory equipment consisted of:

1. Four mooring cable force meters (Figure 4).

2. A six-channel Brush Electronic Compary recording oscillograph, and six Brush Universal Analyzers.

3. A 6-foot by 8-foot by 200-foot wave-towing tank, with bulkhead type wave generator (Figure 12).

4. A 2.5-foot by 64-foot by 150-foot ruodel basin with a flapper-type wave generator.

5. Two $35 \mathrm{mrn}$. Bell and Howell movie caneras.

6. Two clocks and a neon glow tube.

7. A camera box and a camera base plate.

Before the force meters were used their deflection characteristic and their sensitivity to applied cable forces were measured.

Two experimental set-ups were usea, one in the wave-towing tank, other in the Inodel basin. The wave-towing tank was used to deterinine effect of moored vessel dynamics in head seas and the model bosin was used to investigate the moored vessel dynamics in quartering and beam 
MODEL STUDIES OF THE DYNAMICS OF AN LSM

MOORED IN WAVES

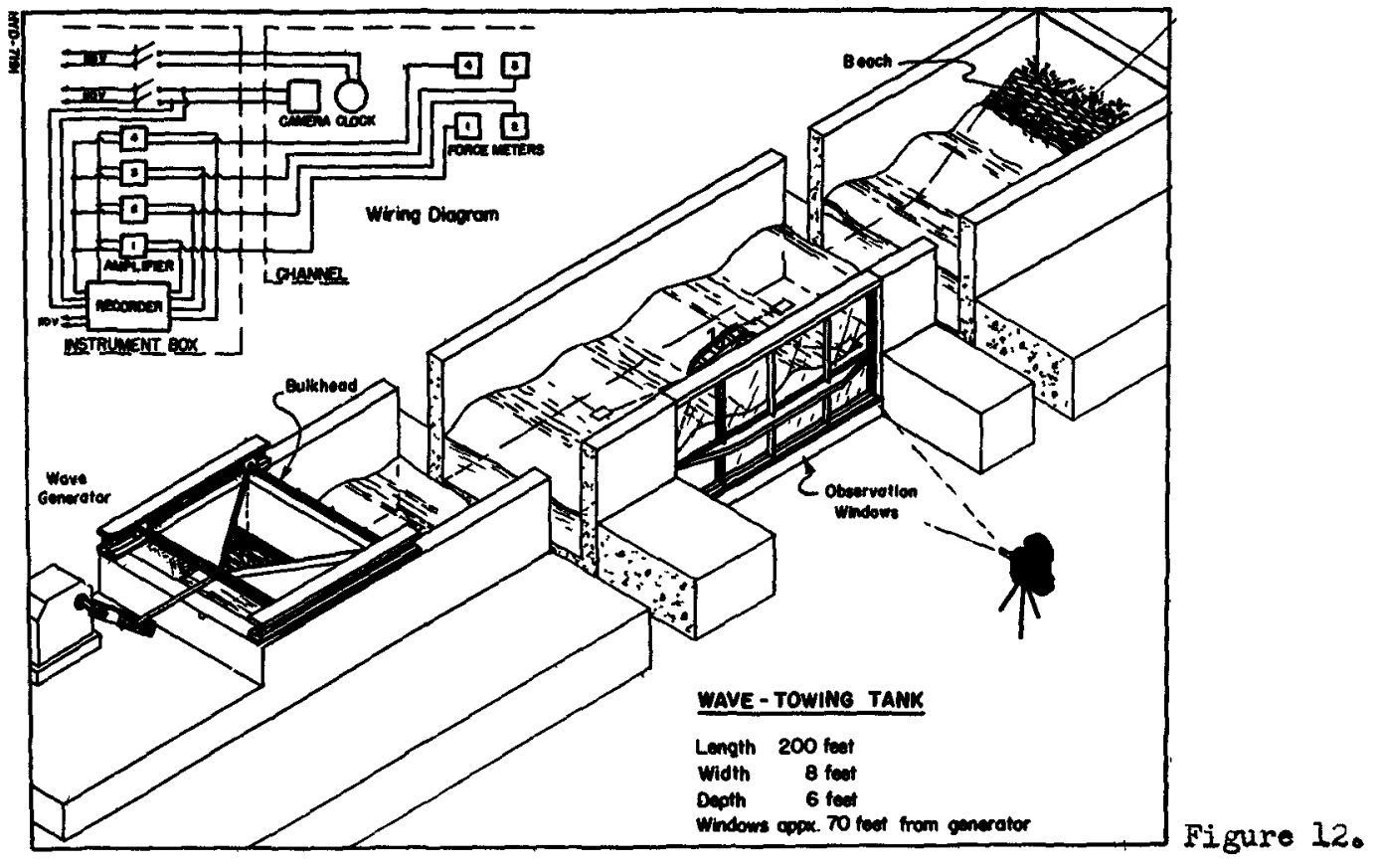

W

U⿺𠃊11

II:

1

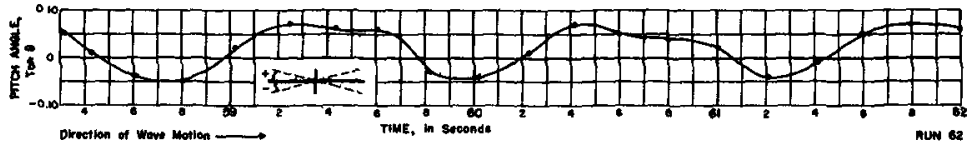

imono 77 F

witus inson

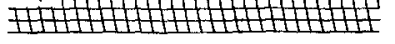

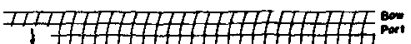

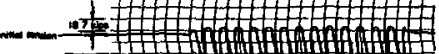

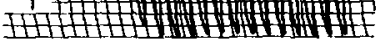

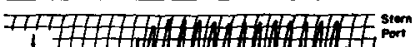

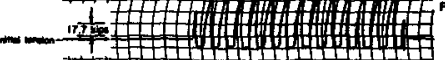

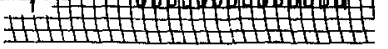

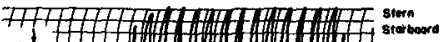

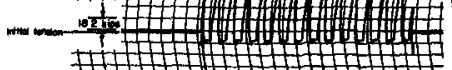

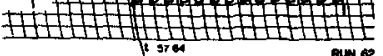

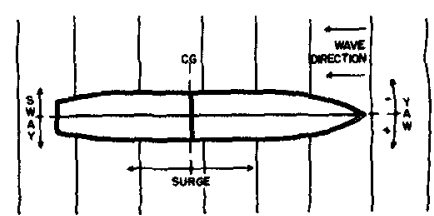

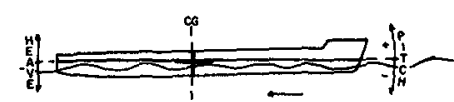

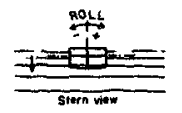

Figure 13.

Sample dita with model LSM in head soas. 


\section{COASTAL ENGINEERING}

A few tests also were run in the madel basin for head seas in order to correlate the results obtained by use of the two facilities. The wavetowing tank wolild have been used for all tests because of the superior control possible with it; however, its transverse dimensions were not ad quate to permit the use of the necessary mooring cable patterns for quar tering and beam seas.

The use and disposition of the cameras and timing equipment (clocks are discussed in the section on Testing Procedure.

\section{TESTING PROCEDURE}

Three testing procedures were followed: one for the head sea test: in the wave-towing tank, one for the quartering sea, beam sea and head: tests in the model basin, and one for the tests in the wave-towing tank of the effectiveness of the large bilge keels.

\section{WAVE-TOWING TANK TESTS}

\section{The following procedure was used:}

1. The depth of water was adjusted to the desired value.

2. A grid was hung from supports across the top of the channel in a plane through the location of the longitudinal axis of model ISM during the tests. Photographs of the grid were taken with $35 \mathrm{~mm}$. movie camera.

3. The grid was removed and the model IsM, mooring cables, and mooring cable force meters were placed in the channel. The mooring cables were attached to the force meters and to the ship model.

4. A desired initial tension was set into the mooring cable system and the force meters were oriented so that the deflection of the entire system would be in scale.

5. A clock was placed just above the snodel.

6. The wave generator was adjusted for a pre-determined wave height and period and the wave generator started.

7. About eight waves were allowed to pass the leeward force meter, then the camera was started, and about two seconds liter both the clock and the force meter recording system were started.

8. After the forces resulting from about ten to twelve waves were recorded on the force-neter recorder, the recorder and clock were stopped. The canera was stopped two secunds later.

9. Steps 7 and 8 were repeated for each wave condition to be tested at one particular mooring condition (scope, water depth, initial tension).

The clocks and force meter recorders were started and stopped at sane tirie while the camera was runing for the purpose of synchronizat Although the clock took about 0.25 second to come up to speed, the fra speed of the camera was known, so that any desired phase relationship tween motions and associated moorins cable forces could be determined. 
MODEL STUDIES OF THE DYNAMICS OF AN LSM MOORED IN WAVES
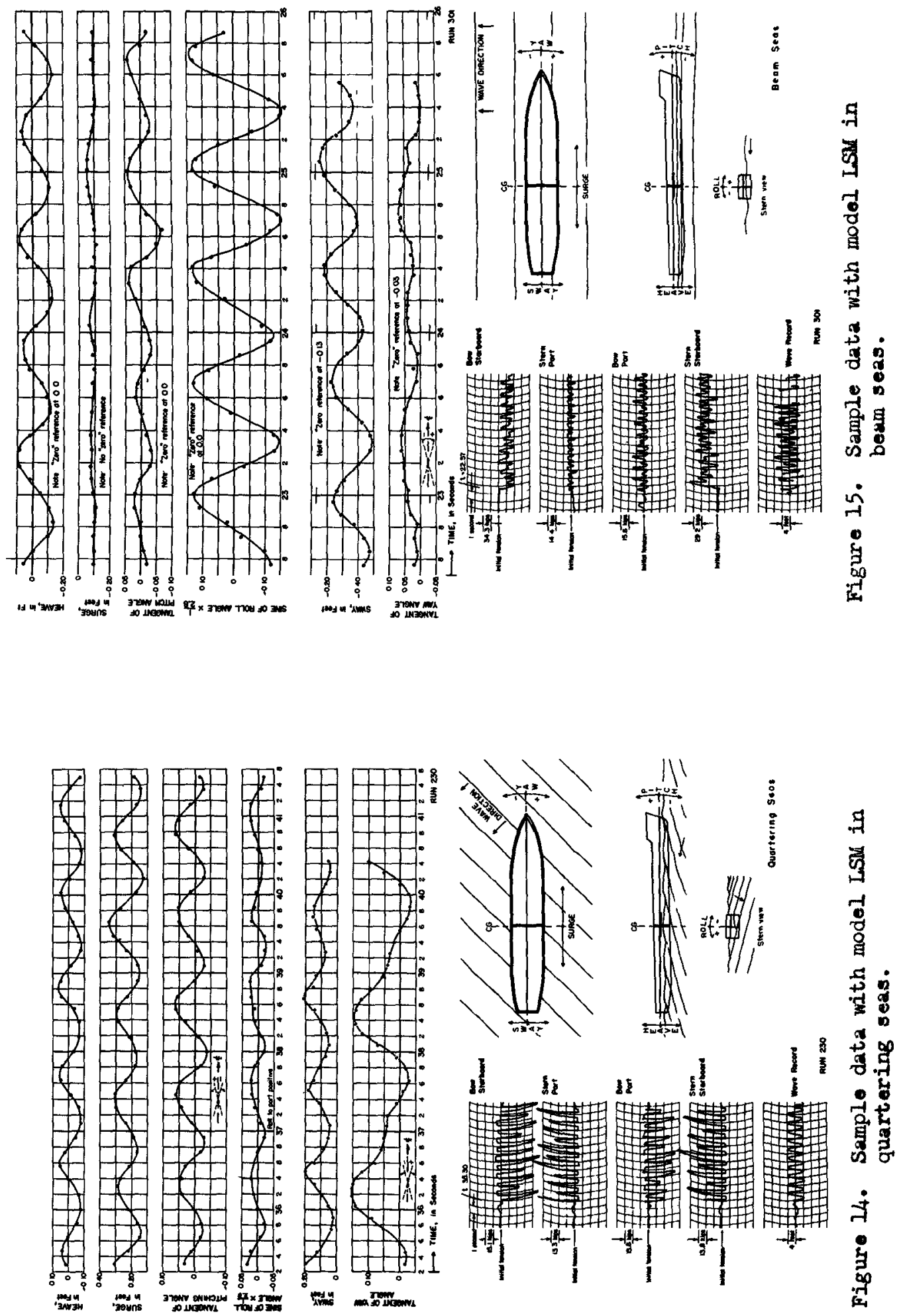


\section{COASTAL ENGINEERING}

The reference for the grid coordinate system consisted of two strip: of black tape, one horizontal and one vertical, pasted to the glass of the channel wall.

\section{MODEL BASIN TESTS}

The model basin tests were performed in the same manner as the wave towing tank, with the exception that two cameras were used. A grid was placed in the plane through the center of the model before the model was placed in the water and a few feet of film were exposed.

\section{ROLL DAMPING TESTS}

The effectiveness of an enlarged bilge keel was tested in the wavetowing tank under "freely floating" conditions; that is, no mooring line were attached. The model was centered in the tank in such a manner tuat it was under the action of beam seas. The data were recorded on $35 \mathrm{~mm}$. movie film.

\section{EXPERIUIENTAL RESULTS AND DISCUSSION}

\section{DATA INTERPRETATION}

Since all experimental data were recorded on either $35 \mathrm{~mm}$. movie fi or on six-channel recording oscillograph paper, it was necessary to reduce this data to such a form that it could be effectively plotted.

The data obtained from the film were plotted as shown in Figures 1 14 and 15. In Figure 13 are shown data for kun 62 for the model LSL in head seas; in Figure 14 are shown data for Run 230 in quartering seas; in Figure 15 are shown data for Run 301 in beam seas. The $r$ anges of cc ditions tested are shown in Table $I$.

\section{FIRST SERIES OF TLSTS}

The first series of tests were conducted to determine the mooring forces and ship motions of a model LSII (1:80 scale) moored in head sea: These tests were made in the wave-towing tank. The pararneters studied this series of tests were initial cable tension, the cable scope, the water depth, the wave height and the wave period.

Two geometric configurations were used in regard to "hawse pipe" cations at the ship's bow. This was because it was noticed that the $w$ spacing of the take-off points of the forward cables was responsible $f$ an induced roll of the model vessel when the vessel was at even a very small angle to the waves; hence, centerline mooring was introduced.

The results of the tests for the centerline-bow, outboard-stern hawse pipe locations are given in Figures 16 and 17. Data were obtair. for wave periods between 6 and 15 seconds and for wave heights betweer 4 and 12 feet (prototype). The least-count" accuracy of the data was about plus or minus five percent. The scatter of data was considerab] 
MODEL STUUDIES OF THE DYNAMICS OF AN LSM

\section{MOORED IN WAVES}

TAELE I. LOORING CUNDITIONS FOR _ODEE ISIĹ

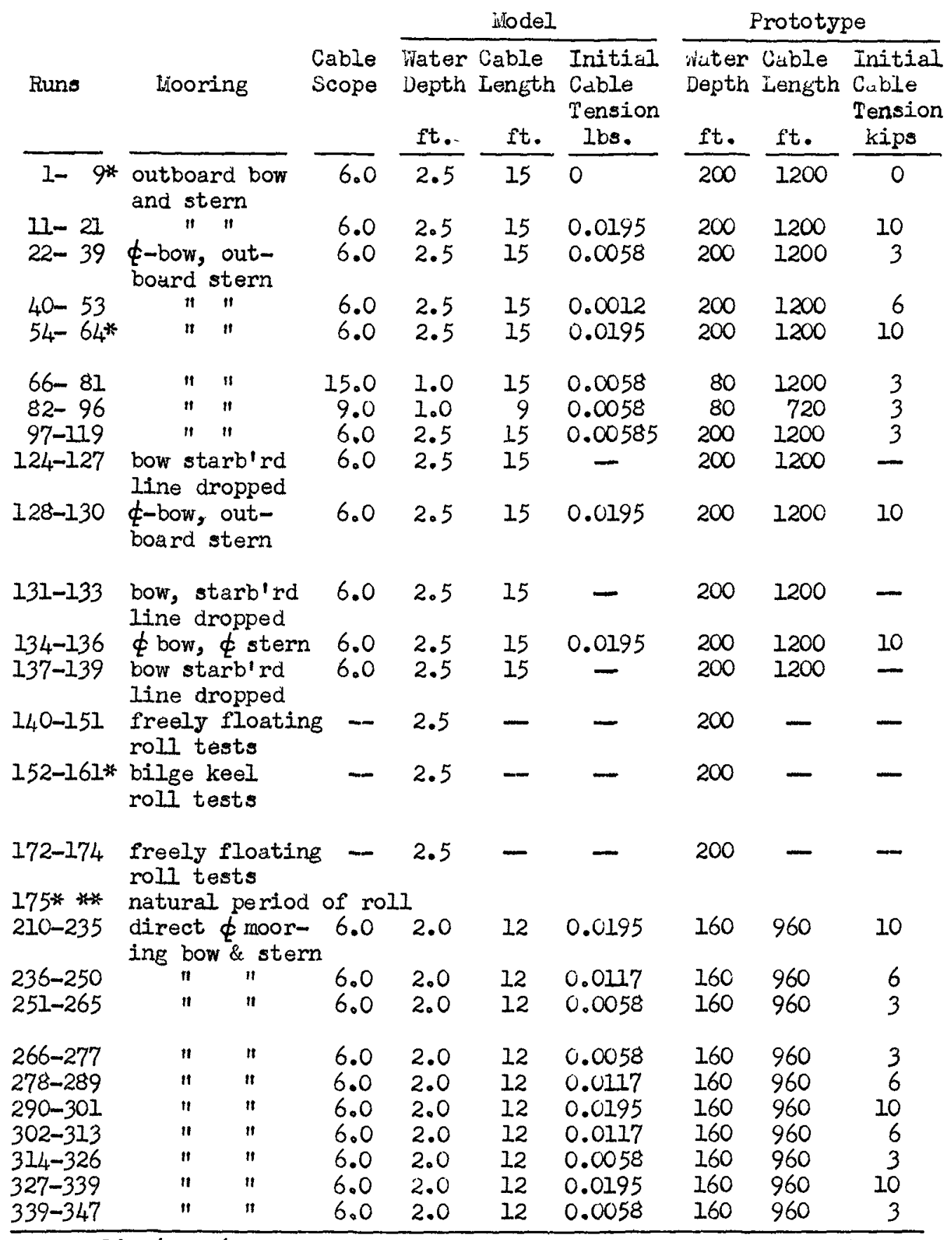

* Runs 10, 65, 162-171 and 200-210 were test runs and are not included. ** Runs number 176-199 were not used. 


\section{COASTAL ENGINEERING}

and much of this was due to the difficulty imposed by the least-count when working with a model of this scale. However, the trends were apparent, and the scatter of data of heave, surge and pitch were probably within the necessary limits from an operational standpoint.

A sample of the data on the horizontal component of cable force at the meter for each cable have been tabulated in Table II, together with the averages of the bow cables, the stern cables and all four cables. T data presented for the individual cables are the maximum recorded forces as rleasured from the initial tension, i.e., the actual horizontal component of force is the tabulated force plus the initial tension. The data on the force records did not show much scatter from wave to wave; thus the scatter is due to the least-count errors and to the fact that the sy tem is rather unstable. Some of the variation in cable force was due tc the inability of the investigators to adjust all four cables to the sarne initial tension. This difficulty, and the result of this difficulty, we particularly apparent in Runs 40 to 53. It is expected, however, that similar difficulties would be encuuntered in prototype; hence, the varic tion of data (particularly in regard to the largest forces measured) should be of considerable value.

The most important fact that was evident in these data was in regal to the relationship between surging motion (and hence cable force) and
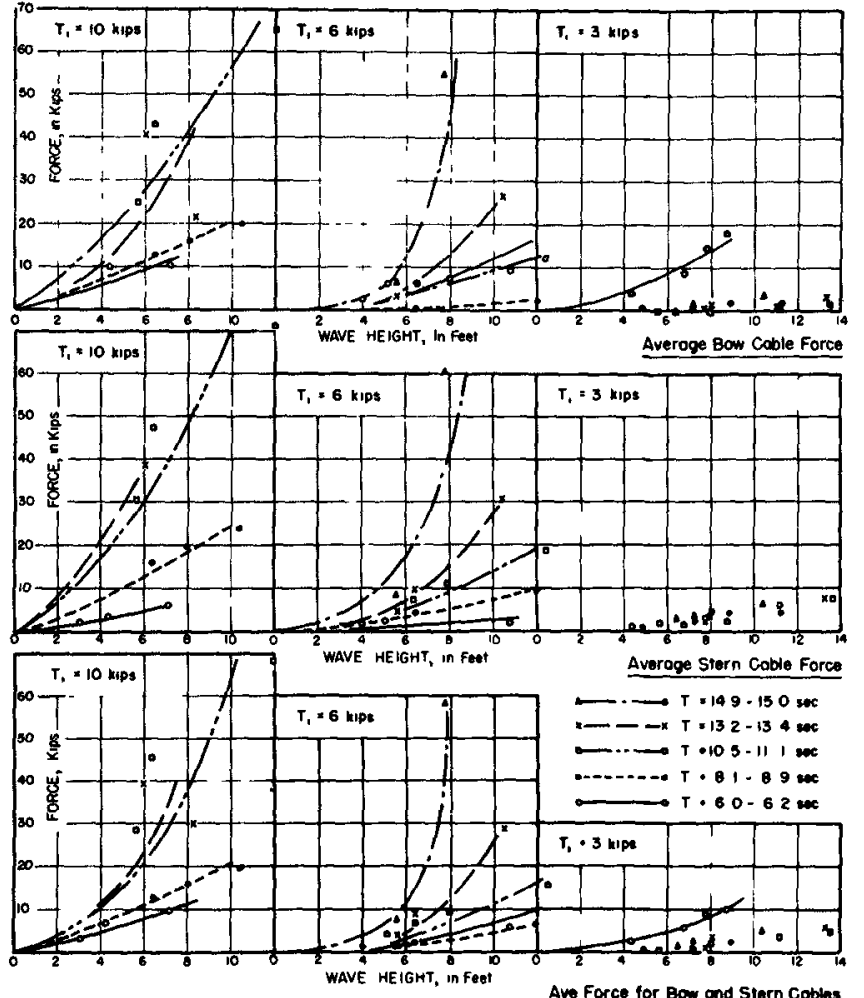

Fifure 15. wooring cable forces in head seds, Runs 22-64. the wdve characteristics. The data showed a resonance condition occurring for certain combina. tions of wave and nooring characteris tics. A check of $t$ surging characteris tics of the test sy tern was underteiken. It was found that $t$ natural period of surge (for the $2 \mathrm{~mL}$ wire with lead shot Wis about 16 seconc for the case of a cable scope of 6 , water depth of $2 \mathrm{CO}$ feet, and an initi: tension of $10 \mathrm{kips}$ (Fizure 18)。 As t] determination of $t$ ] natural period was done with a new se of rlodel cubles, a due to the difficu in obtaining exact initiul tensions, natural perzod of surge during huns I 


\section{MODEL STUDIES OF THE DYNAMICS OF AN LSM MOORED IN WAVES}

TABLE II. SALPLET DATA OF LOTIONS

AIND IROORING FORCES FOR IODUA LSH IN HLAD SEMS

$\begin{array}{llllllll}\text { Run Wave Wave Surge Heave Pitch } & F_{B P} & F_{B S} & F_{S P} & F_{S S} & F_{B_{\text {ave }}} & F_{S_{\text {ave }}} & F_{\text {ave }} \\ \text { No. Period Hejght }\end{array}$ sec. ft. ft. ft. deg. kips kips kips kips kips kips kips Runs 22-39: scope $=6$, water depth $=200$, initial cable tension $=3 \mathrm{kips}$

$\begin{array}{rrrrrrrrrrrrr}22 & 6.0 & 4.4 & 1.5 & 0.8 & 1.6 & 2.7 & 4.6 & 0.4 & 1.6 & 3.7 & 1.0 & 2.4 \\ 23 & 6.0 & 6.8 & 1.6 & 0.8 & 2.3 & 8.9 & 9.0 & 1.5 & 2.3 & 8.9 & 1.9 & 5.4 \\ 24 & 6.0 & 7.8 & 2.0 & 2.4 & 4.0 & 15.2 & 13.7 & 2.1 & 4.4 & 14.5 & 3.2 & 8.9 \\ 25 & 6.0 & 8.8 & 2.0 & 2.4 & 4.3 & 15.2 & 21.1 & 1.4 & 3.0 & 18.1 & 2.2 & 10.2 \\ 26 & 8.1 & 4.8 & 6.9 & 3.2 & 2.3 & 0.3 & 0.3 & 1.2 & 1.2 & 0.3 & 1.2 & 0.8 \\ 27 & 8.1 & 7.2 & 8.7 & 5.2 & 2.9 & 1.0 & 0.5 & 2.3 & 1.9 & 0.8 & 2.1 & 1.5 \\ 28 & 8.1 & 8.8 & 7.6 & 6.4 & 4.0 & 2.0 & 1.1 & 4.0 & 3.5 & 1.5 & 3.8 & 2.7 \\ 29 & 8.1 & 11.2 & 8.8 & 8.0 & 4.6 & 1.0 & 1.6 & 5.5 & 4.4 & 1.3 & 5.0 & 3.2 \\ 30 & 10.5 & 5.6 & 6.0 & 4.0 & 1.7 & -1.1 & 0.3 & 2.2 & 2.0 & -0.4 & 2.1 & 0.9 \\ 31 & 10.5 & 8.0 & 7.2 & 8.0 & 2.3 & -0.3 & 1.9 & 5.3 & 3.2 & 1.3 & 4.3 & 2.3 \\ 32 & 10.5 & 11.2 & 8.8 & 8.8 & 3.4 & 0.5 & 1.7 & 7.2 & 4.6 & 1.1 & 5.9 & 3.5 \\ 33 & 10.5 & 1.36 & 10.4 & 11.2 & 3.4 & 1.5 & 2.6 & 9.2 & 6.8 & 2.1 & 8.0 & 5.1 \\ 34 & 13.4 & 7.8 & 8.3 & 6.6 & 1.7 & 0 & 1.0 & 3.7 & 2.0 & 1.5 & 2.9 & 1.7 \\ 35 & 13.4 & 8.0 & 9.6 & 7.6 & 2.6 & 2.4 & 0.3 & 3.9 & 2.7 & 1.3 & 3.3 & 2.3 \\ 35 a & 13.4 & -1 & -1.4 & - & - & 2.4 & -0.4 & 4.5 & 3.3 & 1.0 & 3.9 & 2.5 \\ 36 & 13.4 & 13.3 & 14.4 & 11.0 & 2.9 & 5.0 & 2.9 & 9.1 & 6.4 & 4.0 & 7.7 & 5.9 \\ 37 & 15.0 & 6.4 & 6.8 & 6.0 & 0.9 & 1.7 & -2.2 & 3.4 & 2.6 & -0.3 & 3.0 & 1.4 \\ 38 & 15.0 & 7.2 & 6.8 & 6.0 & 1.0 & 2.0 & 1.1 & 4.0 & 3.0 & 1.6 & 3.5 & 2.6 \\ 39 & 15.0 & 10.4 & 11.2 & 9.6 & 1.5 & 3.6 & 2.9 & 7.4 & 5.2 & 3.3 & 6.3 & 5.0\end{array}$

Runs 40-53: scope $=6$, water depth $=2001$, initial cable tension $=6 \mathrm{kips}$

$\begin{array}{rrrrrrrrrrrrr}40 & 6.2 & 4.0 & 1.2 & 3.2 & 1.5 & -1.5 & 4.9 & 1.4 & 1.1 & 1.7 & 1.3 & 1.5 \\ 41 & 6.2 & 5.2 & 1.6 & 2.4 & 2.9 & 3.4 & 8.4 & 2.8 & 1.3 & 5.4 & 2.1 & 4.0 \\ 42 & 6.2 & 10.8 & 3.2 & 3.6 & 4.3 & 7.2 & 11.0 & 2.3 & 1.4 & 9.1 & 1.9 & 5.5 \\ 43 & 8.8 & 6.4 & 5.6 & 5.6 & 2.9 & -1.2 & 1.4 & 6.6 & 2.1 & 0.1 & 4.3 & 2.2 \\ 44 & 8.8 & 8.0 & 1.0 & 6.4 & 3.4 & - & - & - & - & - & -1 & -1 \\ 45 & 8.8 & 12.0 & 8.8 & 7.6 & 4.9 & 0.2 & 5.8 & 13.2 & 6.4 & 3.0 & 7.0 & 6.4 \\ 46 & 10.9 & 6.4 & 7.2 & 6.0 & 1.5 & 5.2 & 7.7 & 11.0 & 3.4 & 6.5 & 7.2 & 6.9 \\ 47 & 10.9 & 8.0 & 9.6 & 7.2 & 2.3 & 2.7 & 11.6 & 16.6 & 6.4 & 7.1 & 11.5 & 9.3 \\ 48 & 10.9 & 12.4 & 13.6 & 5.2 & 3.2 & 5.7 & 18.7 & 26.0 & 11.9 & 12.2 & 18.9 & 15.6 \\ 49 & 13.2 & 5.6 & 5.6 & 3.6 & 1.1 & 0.4 & 6.2 & 7.6 & 1.5 & 3.3 & 4.6 & 4.0 \\ 50 & 13.2 & 6.4 & 8.8 & 6.4 & 1.4 & 2.6 & 10.4 & 14.4 & 4.7 & 6.5 & 9.6 & 8.1 \\ 51 & 13.2 & 10.4 & 19.2 & 9.6 & 2.4 & 13.8 & 39.1 & 42.1 & 19.7 & 26.5 & 30.9 & 28.7 \\ 52 & 14.9 & 5.5 & 7.7 & 4.4 & 1.0 & 2.2 & 10.8 & 13.0 & 4.0 & 6.5 & 8.5 & 7.5 \\ 53 & 14.9 & 7.7 & 33.5 & 7.6 & 1.4 & 50.2 & 59.0 & 61.8 & 61.2 & 54.6 & 61.5 & 58.1\end{array}$

Note: $F_{B P}$, force c.easured for port bow cable; $F_{B S}$, for starboard bow cable; FSP, for port stern cable; and $F_{S S}$, for starboard stern cable. 

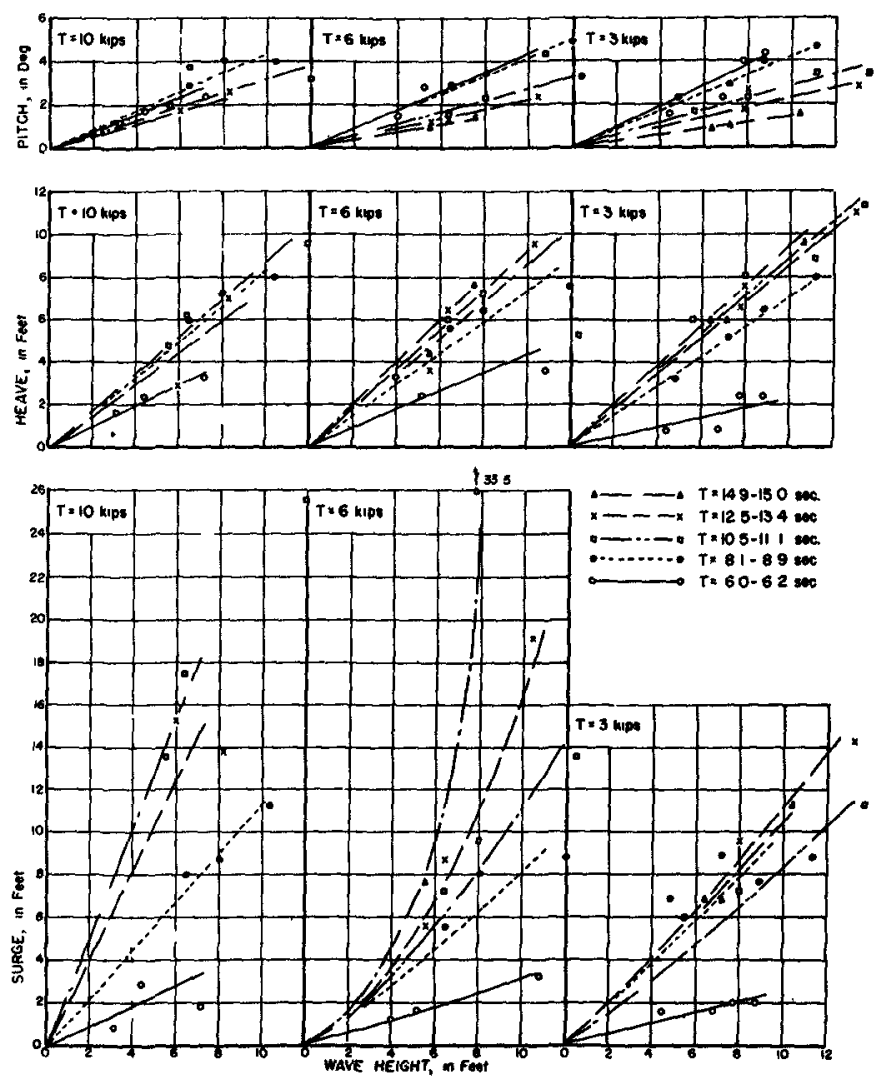

Figure 17. Pitch, heave and surge in head seas, Runs 22-64. might well have been a few seconds less. It was evident from the data in Table II and Figures 16 and 17 that the relationshif between both surging and cable force and the wave height was non-linear, at least when near resonance. Both the surging motion and tue cable force increased quit, rapidly for the creater wave heights

It is apparent that this difficulty would not be encountered when operation were conducted in an area where the wave period was in the vicinity of 5 to 8 seconds, nor would i become apparent for low waves (say, in $t$ neighborhood of $3 \mathrm{ft}$ due to the inability of a person to judg! the extent of such small motion.

It was found that for the case of low initial cable tension, the highest mooring cable forces were associated with the shortest wave period; however, as the initial tension increases, the highest forces were associated with the longer periods - those nearer, or at, resonan

In regard to the vessel motions, what was realy needed was its spatial location as a function of time. The tremendous amount of calcu lations necessary to present this information precluded obtaining it on this investifation, and instead the individual motions were shown in $r e$ lation to the wave height and period. These data have been presented $j$ Figure 17. It was found that the pitching angle was nearly a linear if tion of wave height with the shortest period (within the limits of the experinents) beina responsible for the ereatest pitch. The pitching ancle appeared to be independent of the initial cable tension. lleave $v$ breatest for the longest wave periods and appeared to be independent of the initial cable tension.

Surgine motion was depencient upon initial cable tension to a grea desree. In addition, it wus not linearly related to wave height; rath 


\section{MODEL STUDIES OF THE DYNAMICS OF AN LSM MOORED IN WAVES}

it increased with wave height at an increasing rate, at least where the period was in the vicinity of resonance.

\section{SECOND SERIES OF TESTS}

The model cable first used ( 2 mil diameter wire with lead shot attached for weight) was found to deteriorate very rapidly in use; hence, very small forces would break the cables during tests. Califormia Research Corporation and University of California personnel agreed that a $10 \mathrm{mil}$ wire should be used if tests indicated that the result would correspond with those obtained using the 2 mil-with-shot wire, and providing swivels were used at points of attachment, and kinks in the wire avoided.

In order to determine the difference in effects in mooring dynamics due to the use of two types of mooring wires, a series of tests were run. At the same time the effect of "breaking" one cable was studied, as was the effect of introducing a centerline mooring "hawse pipe" at the stern of the model. The date were compared with the results of provious tests and were found to be in fair agreement provided the differences in natural period of surge are kept in mind. For example, in the case of an initial cable tension of $10 \mathrm{kips}$, a resonance, or near-resonance, condition for the 2 mil-with-shot cable occurred for both Runs 63 and 18 ( 12.5 and 13.0 second wave, respectively) while for the $10 \mathrm{mil}$ wire this condition occurred for Run 129 (a 9.2-second wave period). This can readily be understood by exaraining the curves of natural period of resonance versus initial cable tension in Figure 18.

As a part of this same series of tests data were obtained which showed the effect of one mooring cable breaking. The tension in the diagonally opposing cable dropped off considerably and the vessel yawed slightly, slacking off the remaining two cables (from an "initial tension" standpoint). This caused an increase in the natural period of surge. Hence, the resonance occurred at a greater wave period. For exanple, a resonance

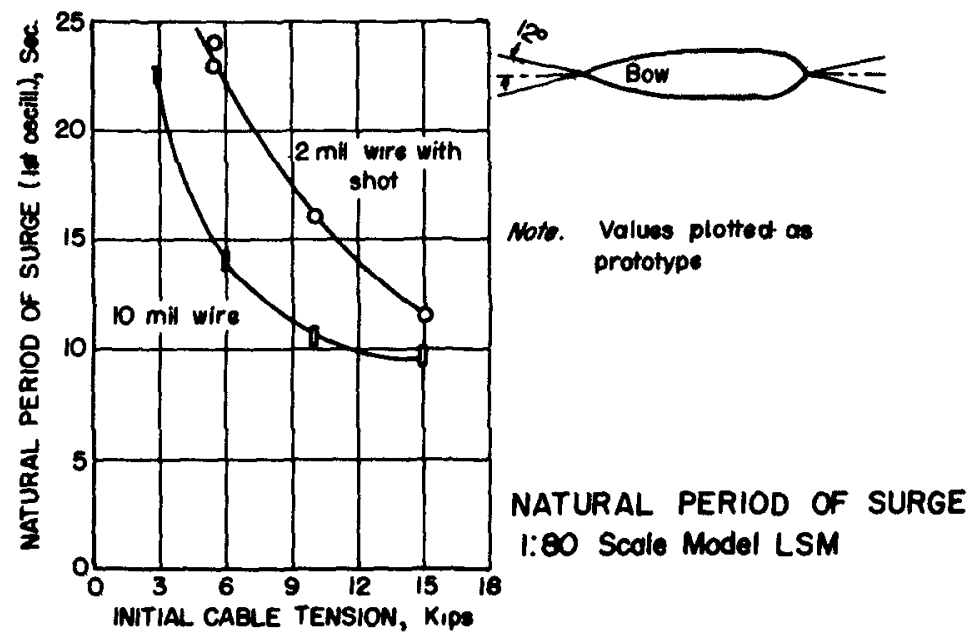

Figure 18. 


\section{COASTAL ENGINEERING}

or near-resonance condition occurred for a wave period of 9.2 seconds fo the 10-kip initial cable tension with four mooring lines, but shifted to 13.5 seconds when the starboard bow cable was dropped. It was not possi ble to tell conclusively from these data whether dangerously high forces will be experienced when one cable breaks, because of the spread of wave periods tested, with the resulting probability that the peak resonance condition might have been encountered for the 13.5-second wave but not $f$ the 9.2-second wave, vice versa, or neither.

Data were also obtained for a centerline stern mooring. The effect of this type of mooring was not apparent unless there was an induced rol

\section{THIRD SERILS OF TESTS}

In order to test the effect of roll-damping devices, it was necessa to use the wave-towing tank, which in turn prevented the testing of a properly-moored vessel. Because of this, the effect of the device was studied for the freely-floating condition. The data have been given in Table III. The roll was considered in two parts, as shown in the follor ing sketch:

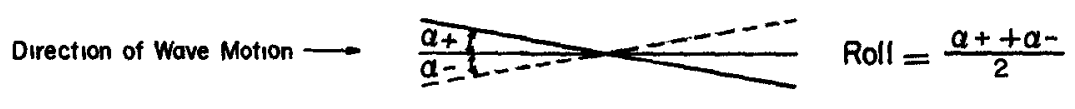

$\alpha+$ was the angle of roll as measured upwards on the up-wave side of th vessel, wile $\alpha$ - was the angle of roll as measured downwards on the $u$ wave side of the vessel. It can be seen in Table III that at was con sistently larger than $a-$. This was a dynarnic characteristic of the interaction between the waves and the vessel and was probably a result diffraction. It did not occur during tests for natural period of roll; hence, it was not caused by some unbalance in the vessel. This "dynami list" was most apparent for the case where bilge keels were added. The bilge keels were very effective (especially for the short period waves) when one considered the mean roll from its dynamic equilibriurn positior (i.e., $\alpha++\alpha-12$ ); however, it was not nearly so effective when the maximum roll $(\alpha+)$ from the horizontal was considered.

\section{FOURTH SERISS OF TESTS}

The fourth series of tests was performed to determine the vessel motions and mooring forces in quartering and beam seas. In addition, : tests were made of the vessel in head seas. This was done so that a cr parison could be made between the tests in the model basin and the tes in the wave-towing tank. Due to the limitations of the model basin it was possible to moor the vessel in no more than 160 feet of water (pro totype). 10-mil model nooring cables were used. Some of the data hav been plotted in Figures 19 to 2l. In addition to a least count accura of $\pm 5 \%$ the data obtained in the model basin are subject to variations as the wave generator motion is not as consistent as in the wave-towin tank and because it was not possible to have complete protection from wind effects on the model. 


\section{MOORED IN WAVES}

TABLT III. EFFECT OF HULA DAWPING DEVICES

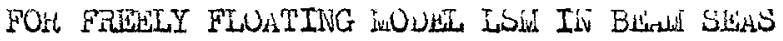

\begin{tabular}{|c|c|c|c|c|c|}
\hline $\begin{array}{l}\text { Kun } \\
\text { Ho. }\end{array}$ & $\begin{array}{l}\text { Wave } \\
\text { Period } \\
\text { sec. }\end{array}$ & $\begin{array}{l}\text { wave } \\
\text { Height } \\
\text { ft. }\end{array}$ & $\begin{array}{l}\text { Hve. } \\
\alpha+ \\
\text { deg. }\end{array}$ & $\begin{array}{l}\text { Ave. } \\
a- \\
\text { deg. }\end{array}$ & $\begin{array}{l}\text { Range of } \\
\text { Roll } \\
\text { deg. }\end{array}$ \\
\hline Runs & $140-151$, & no roll & damping & devices & \\
\hline $\begin{array}{l}140 \\
141 \\
142 \\
(143)\end{array}$ & $\begin{array}{l}6.3 \\
6.3 \\
6.3\end{array}$ & $\begin{array}{l}1.2 \\
2.1 \\
6.3\end{array}$ & $\begin{array}{r}5.0 \\
10.0 \\
12.3\end{array}$ & $\begin{array}{r}4.2 \\
8.0 \\
10.2\end{array}$ & $\begin{array}{r}3.3-4.5 \\
8.5=9 \\
11.0=11.5\end{array}$ \\
\hline $\begin{array}{l}144 \\
145 \\
(146)\end{array}$ & $\begin{array}{l}7.8 \\
7.8\end{array}$ & $\begin{array}{l}4.6 \\
7.9\end{array}$ & $\begin{array}{l}5.0 \\
8.2\end{array}$ & $\begin{array}{l}3.7 \\
7.0\end{array}$ & $\begin{array}{l}4.3-4.5 \\
6.3-8\end{array}$ \\
\hline $\begin{array}{l}147 \\
148 \\
149 \\
150 \\
151\end{array}$ & $\begin{array}{r}7.8 \\
7.8 \\
12.5 \\
12.5 \\
12.5\end{array}$ & $\begin{array}{r}7.1 \\
17.6 \\
3.2 \\
5.8 \\
8.2\end{array}$ & $\begin{array}{r}7.5 \\
11.5 \\
2.5 \\
2.5 \\
3.9\end{array}$ & $\begin{array}{r}6.7 \\
10.0 \\
1.7 \\
1.5 \\
3.2\end{array}$ & $\begin{array}{l}7-7.3 \\
10.5-11 \\
1.5-2.0 \\
1.8 \\
2.3-3.6\end{array}$ \\
\hline
\end{tabular}

iouns 152-161, with bilge keel

$\begin{array}{lrrrrl}152 & \text { natural period of roll }=11.9 \text { seconds } \\ 153 & 0.3 & 5.4 & 4.3 & 1.0 & 1.5-3.5 \\ 154 & 6.3 & 10.1 & 10.2 & 0.9 & 3=7 \\ 155 & 6.3 & 1.6 & 3.0 & 0 & 1.3-1.8 \\ 156 & 7.9 & 3.8 & 4.6 & 0 & 1.8-3.3 \\ 157 & 7.9 & 7.7 & 6.5 & 0.3 & 2.5-4.0 \\ 158 & 7.7 & 11.0 & 8.4 & 0.7 & 3.5-6.5 \\ 159 & 12.9 & 3.5 & 2.0 & 1.0 & 1.3-1.0 \\ 160 & 12.9 & 6.6 & 2.7 & 2.0 & 2.3 \\ 161 & 12.9 & 9.5 & 3.5 & 2.5 & 3.0\end{array}$

IRuns 172-175, no roll damping devices

$\begin{array}{rrrrrrr}172 & 6.1 & 1.4 & 9.4 & 8.0 & 7.3-9.5 \\ 173 & 6.1 & 4.6 & 12.3 & 11.8 & 11 & -15 \\ 174 & 6.1 & 7.5 & 20.6 & 18.6 & 19 & -22 \\ 175 & \text { natural period of roll } & -5.1 \text { seconds } & \end{array}$

Note:

1. AII values tabulated are for the prototype.

2. RoIl $=\frac{\alpha++\alpha-\alpha}{2}$, where $\frac{\alpha+}{g=\ldots+}$

3. Waximum variation of \pm 1 degree for roll angle for no damping device. The variation was up to \pm 2 degrees for the case of the bilge keel; near resonance cunditions may be larger.

4. The tine history records of the roll motion of the freely floating nodel LSim can be considered to be of two types: 1. the rolls were nearly uniform; and 2. the roll were irregular. The data presented in Table III 


\section{COASTAL ENGINEERING}

TABLE III. Note (cont.)

are of two types: 1 , $\alpha+$ and $\alpha-$ which are the values of straight lines put on the records by eye to represent the average position of the roll up and the roll down; and 2. range of roll, wich shows the range of roll angles as measured from the roll down position to the following roll up position.

An examination of the forces in the mooring cables for head seas as obtained in the wave-towing tank and the model basin for the same initial cable tensions and cable scopes, but different water depths, (Fi ure 16 and 2la) showed that they compared reasonably well considering th difference in model cables. This was also true of the pitching and hear ing motions (Figures 17, 20a and 21a). Considering the fact that ocean waves are non-uniform in both amplitude and period and the possibility exists of a particular wave period component forcing the vessel in resonance, it would appear that the comparisons of the two sets of data witl respect to maximum probable vessel motions and mooring cable forces are good.

It can be seen that the vessel rolled, yawed and swayed even thougl it was in "head seas". It is not possible to fix the vessel heading exactly, and any induced motion would be emphasized by the elastic moor ing cables. In addition, there may be an inherent instability as discussed by Grim (1952).

In regard to motions in quartering seas, it can be seen that the surge and pitch amplitudes are of the same order of ruagnitude as for th head seas tests in the model basin. The difference in water depth (160 feet rather than 200 feet) should not be of any significance as both depths are relatively deep as far as the water particle velocities and accelerations within the surface layer of the same thickness as the ves sel's draft. The heaving amplitude is greater than for head seas; in fact, the heaving exceeded the wave height on many occasions. A portic of this can be attributed to the effect of angular distortion; however, it is mainly due to the fact (Weinblum and St. Denis, 1950) that the heaving force function increases with increasing angle between the shi] bow and the wave direction (see Figure 5a). This, combined with the mat nification factor (Figure 5b) for a daruping coefficient of 0.4 (approx mutely the value for an average ship), leads to a heaving amplitude wh can be in excess of the wave amplitude. In addition, there is considerable sway, roll and yaw. An example of the type of data obtained ha been given in Figure 14. It was apparent from the tests that the sway and yaw records may be either fairiy uniform or quite non-uniform. Th record in $\mathrm{Fi}_{b}$ ure 14 cannot be said to be typical; rather, there was an entire spectrum of variations. These two motions appeared to get in a out of phase for certain wave periods; maximum values of away and yaw often as much as 25 percent greater than the average values reported $i$ the tables. The mooring cable forces were of the same order of magnit as in head seas and the trends appeared to be the same as in head seas 
MODEL STUDIES OF THE DYNAMICS OF AN LSM MOORED IN WAVES
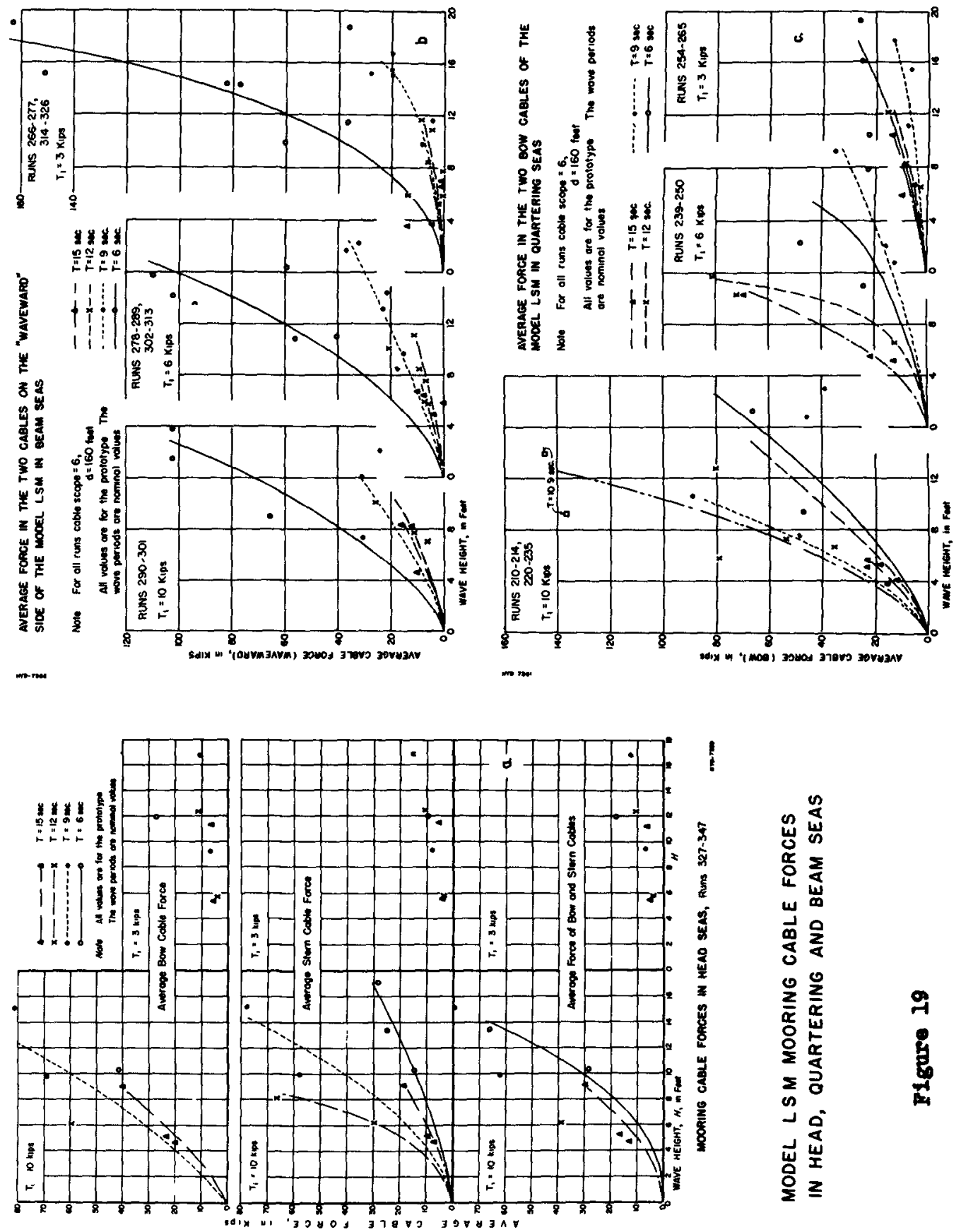


\section{COASTAL ENGINEERING}
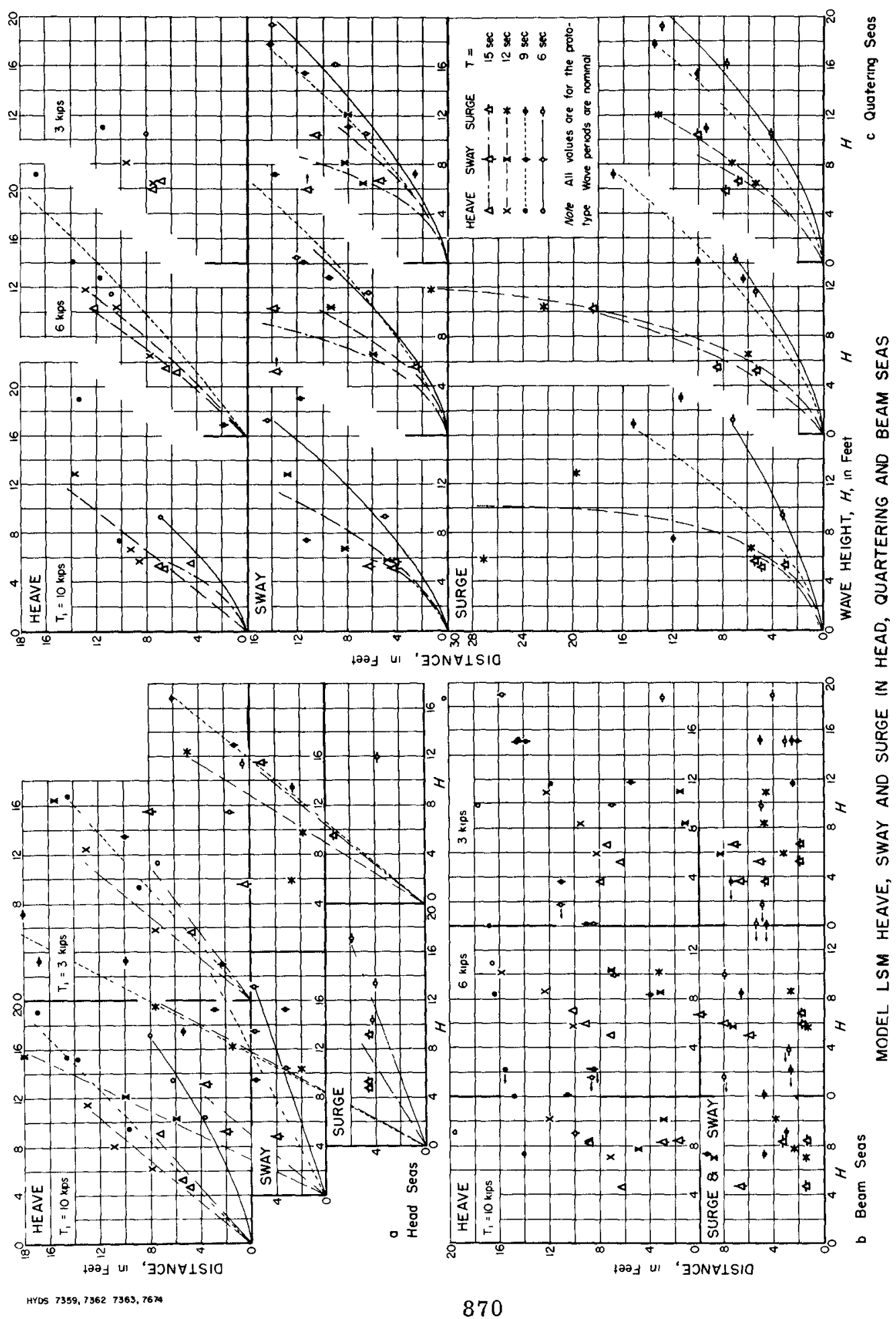

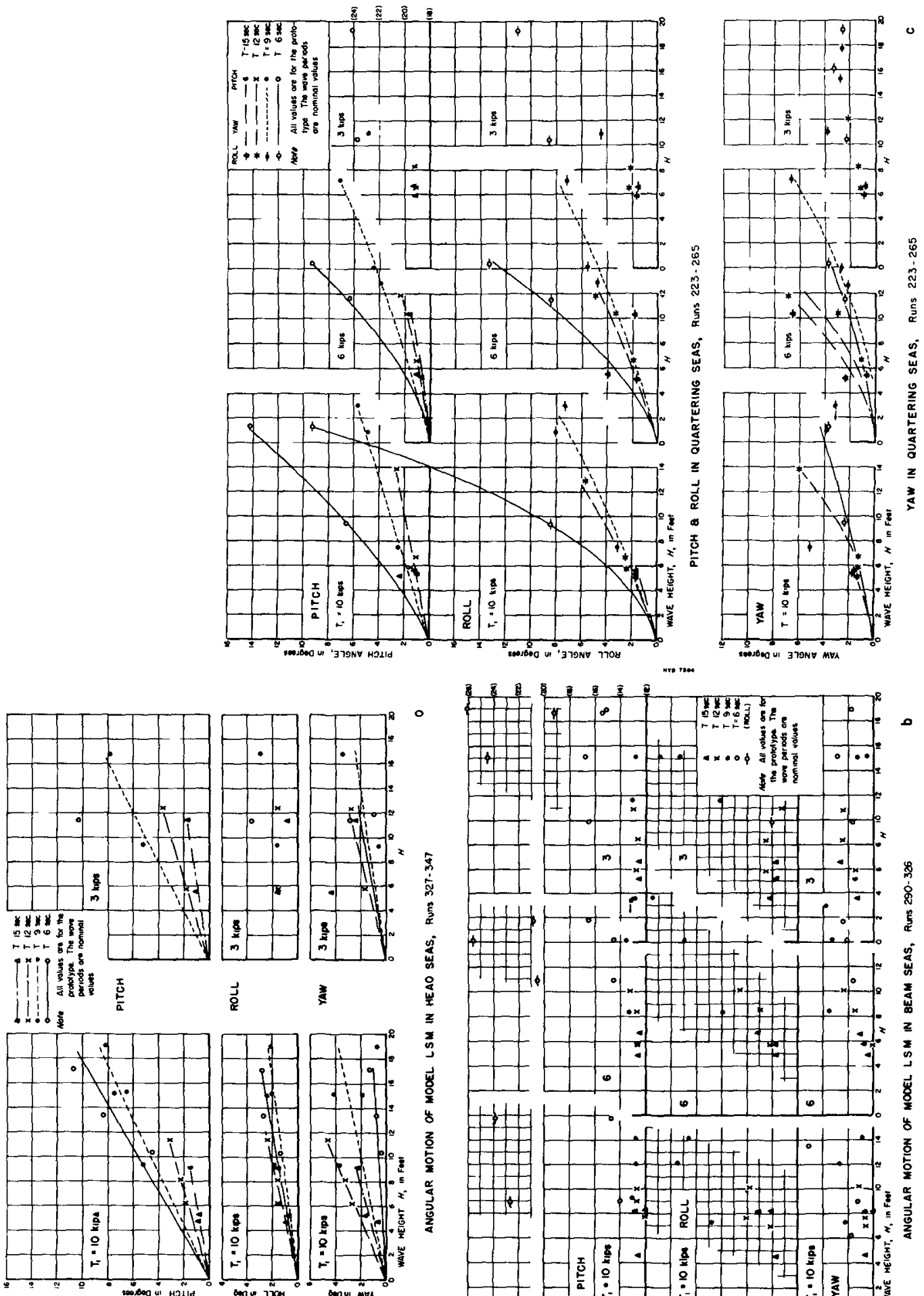

索
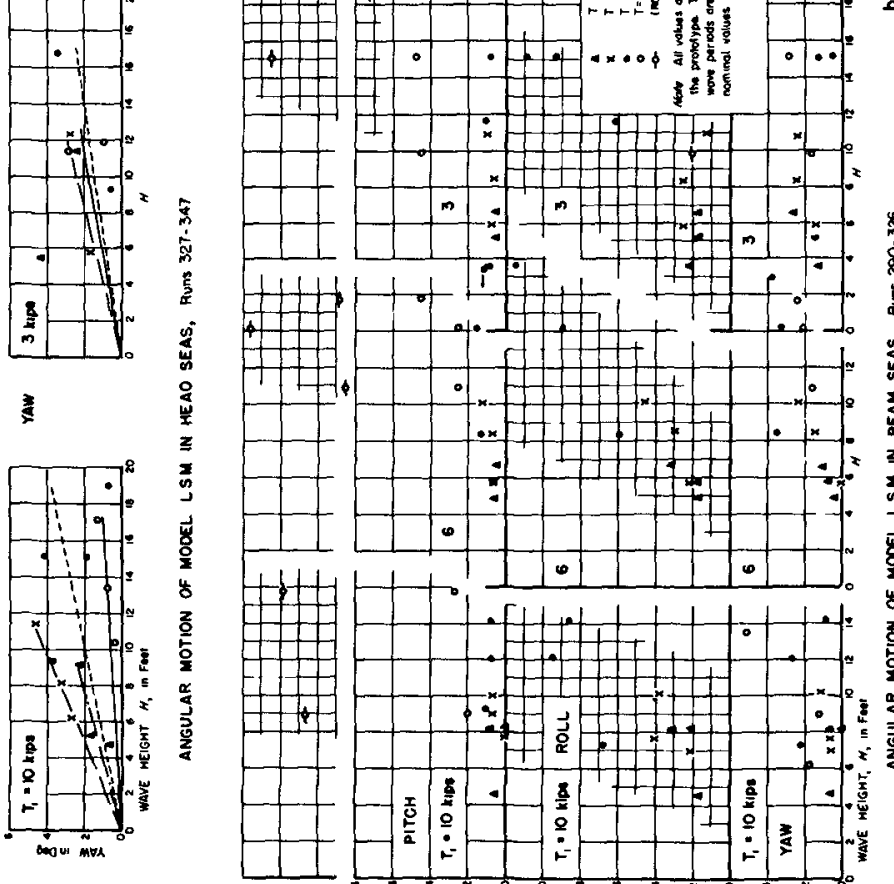

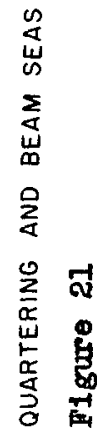
完

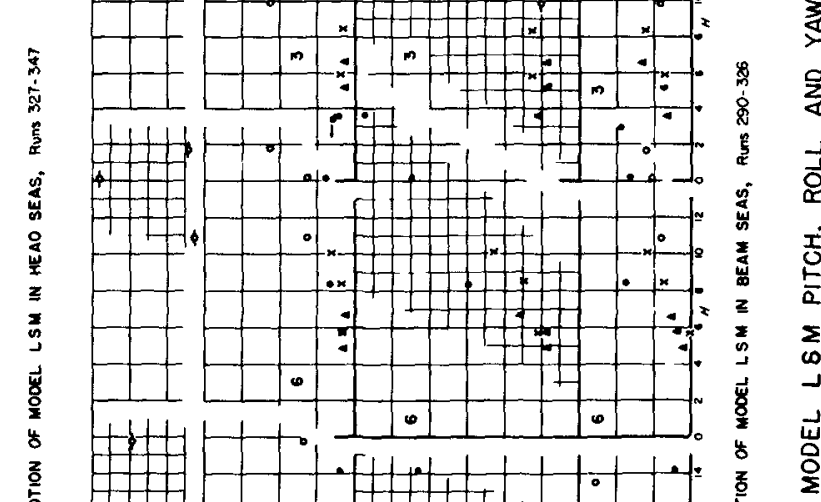




\section{COASTAL ENGINEERING}

In beam seas the surging motion decreased considerably, althouth it did not go to the zero. This was possibly due to a small error in the positioning of the vessel, unequal initial cable tensions, or both. The same was true for pitching. The yawing was appreciable, although the magnitude was not as creat as for the case of quartering seas. The roll. ing motion appeared to be of about the same order of magnitude for beas. for quartering seas. The sway increased. It was evident that large motions could be expected for certain combinations of wave heights and periods. The reason for the apparent "resonance" condition occurring fo sway in beam seas was not apparent considering the long natural period. It was evident from Figure $2 \mathrm{Ib}$ that it was nearly independent of initial cable tension. However, it well may be explained if curves similar to Figure 5 were available. Certainly the "swaying force furction" must be very large. The ratio of the maximurn values of sway to wave height neve approach the maximum value of the ratios of surge to wave height.

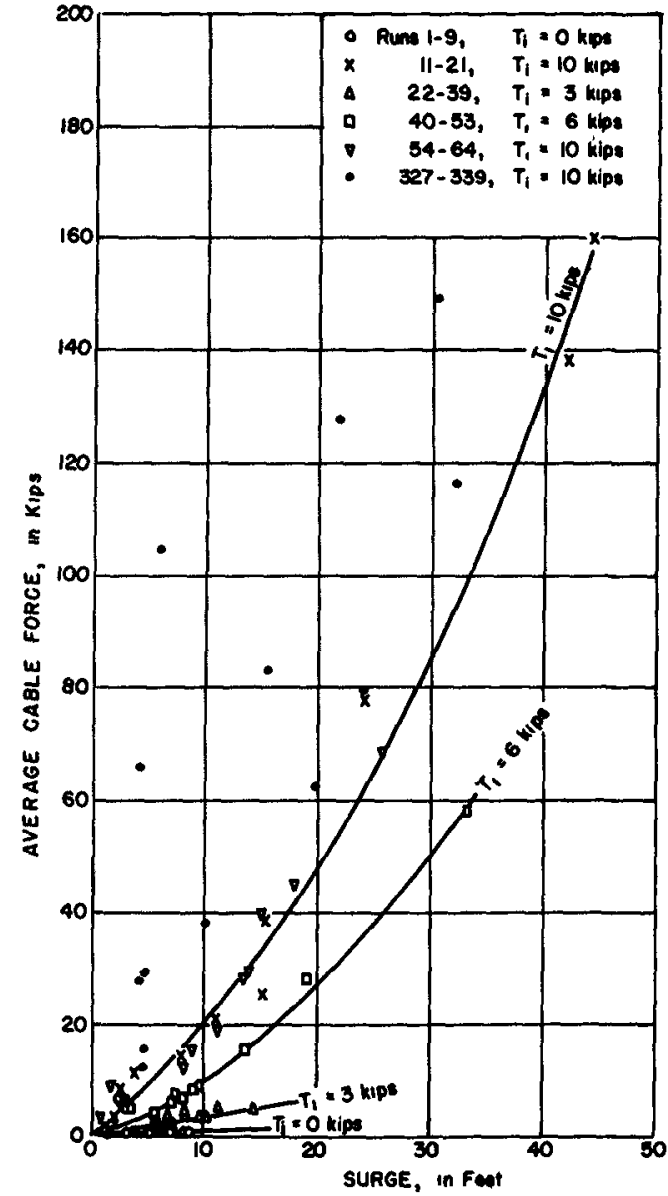

AELATIONSHIP BETWEEN AVERAGE MOORING CABLE FORGE AND SURGE IN HEAD SEAS

Figure 22.
The maximum cable forces occurred for lower wave periods in beam seas than in eithe head or quartering seas. Thu it might be necessary to head the vessel differently, deper. ding upon the wave period (say, local seas or swell).

GENERAL

The average cable force data have been plotted in Ficure 22 in relation to the vessel surge for three initi: cable tensions for the vesse] in head seas. The data taker in the wave-towing tank show a marked degree of correlatis In addition, the data taken the rnodel basin (for an init cable tension of $10 \mathrm{kips}$ ) we plotted. Some of the data were not consistent. Some waves used in the model basi were considerably higher tha was the case for the tests i the wave-towing tank and the data which were most out of agreement were those dssocia with the highest waves and $t$ accompanying large pitching and heaving. It is believed that for waves under, say, 12 feet in height, the relationship shown in Figure 22 should be valid. 


\section{MODEL STUDIES OF THE DYNAMICS OF AN LSM \\ MOORED IN WAVES}

The bow cable force for the model in head seas were considerably higher than the stern cable forces for the shortest wave periods used. For longer wave periods this relationship was reversed, while the longest waves tested showed the relationship often reversed agdin. The ratio of the average bow cable forces to the average stern cable forces have been plotted in relationship to the wave period in Figure 23. The curve was found to drop abruptly at about $6 \frac{1}{2}$ seconds to a minimum value and then to increase with increasing wave period.

The data could have been plotted as a function of the dimensionless parameters $\lambda / L$ (ratios of vessel length to wave length) and $H / L$ (ratio of wave height to wave length). This was done for a few cdses for checking purposes. However, it does not clarify the understanding of the phenomena as anly one ship model length, $\lambda$, was used; hence, the dimensionless numbers would have no significance.

\section{CONCLUSIONS}

The problem of the prediction of notions of a freely floating vessel in a seaway has not been solved completely. The motions of a moored

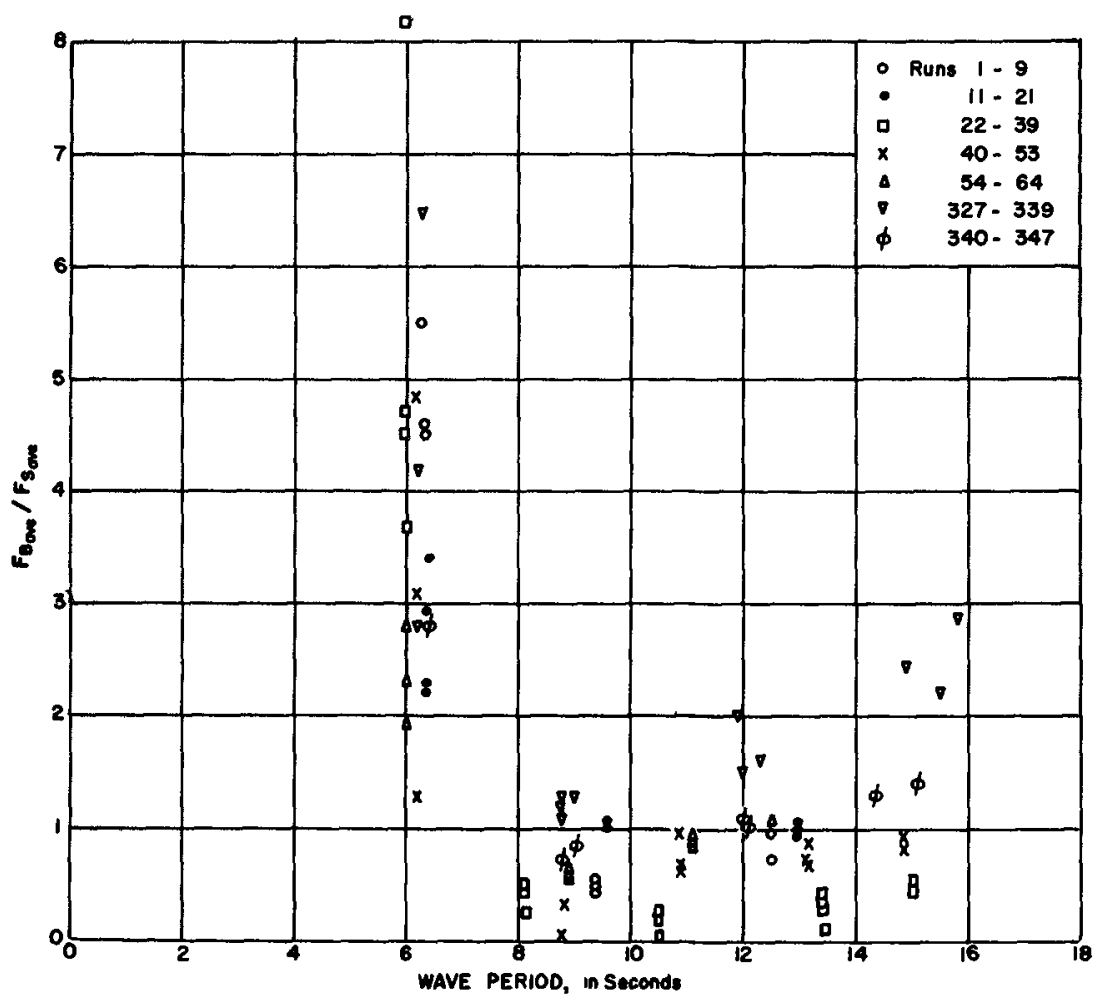

Relationship between the waVe period and the ratio of the aVerage BOW MOORING CABLE FORCE AND AVERAGE STERN MOORING CABLE FORCE

Figure 23. 


\section{COASTAL ENGINEERING}

vessel are mach wore complicated and require an expirical solution at the present time. From a practical standpoint the nost importint differeace between the motions of a freely floating and a moored vessel is the possi bility of resonance conditions occurring in the surging, swaying and yawing motion of a moored vessel, as sell as in the heaving, pitching and rolling notions.

Resonance conditions were found to occur in the surging motion of th rodel in both head and quartering seas; resonance conditions were found $t$ occur in swaying and heaving notion in both quartering and beam seas (esp cially in beam seas), although the magnification factor for swayin wias not nearly as high as for the case of surging. The greatest forces in tr mooring cables occurred at these resonance conditions.

The natural periods of surge, sway and yaw were found to be critica. dependent upon the mooring cable conflguration and initial tension, with the greater the initial tension the shorter the natural period. lledving. pitching, and rolling appeared to be essentially independent of the initial cable tension within the linits of the experimental range of conditions; if they were not independent the relationsnis was nasked by the experimental scatter. The natural periods of sway and yaw for the range of initial cuble tencion used in the tests were found to be much greater than the periods of weves normally encountered in the ocearl. The resonance condition for surging for the hisher initial cable tensions used $i$ the tests was found to occur within the range of wave periods normolly e pected along the Pacific Coast of the United States. The relationsnip Letween the surging notion (and mooring cable forces) and wave neight wa non-linear, at least when near the resonance condition. The sureirio motions and cable forces were found to increase at increasing rates whth ircreasing wave height.

It wes found that the higher the initial cable tension the greater were the maximum cable forces experienced when the vessel was subjected to wave action in head or quarterintô seas. This was because resonance conditions occurred for wave periods in the range of 10 to 15 seconds. However, in the case of bean seas the cable forces were found to be reli tively indeperdent of the iritial tension. In this case the Iuaxinum cable forces occurred for the shortest wave period tested (about 6 secunds). These occurred in the cables on the "waveward" side of the rodel. "t the sime time, the forces on the "downwave" cables were relatively small. It would appear that the high forces on the "wavewdrd" cables were due to a combination of diffraction and second order effect: for this case.

The data on heaving, pitching, rolling and yawing were relatively consistent and it should be possible to deterisine these wotions for the prototype with an acceptible degree of accuracy.

Conslderine the difflculties znherent in obtaining quantitative results using a snill model, and where no prototype sueasurenents are availible to use as a suicie, the results of the nouring cuble force wed urenients are not too inconsistent. Certannly the trends can be relied $u_{i}$ on of curl the order of wagnitude of the wotions and the cable forces. 


\section{MODEL STUDIES OF THE DYNAMICS OF AN LSM MOORED IN WAVES}

This is especiully true when the ron-uniformity of ocean waves is considered.

ivone of the notions or cable forces appear to be excessive for a wave height in the neighborhood of 5 feet, regardless of wave period. waves in excess of 8 feet (wore or less), on the other hand, might result in high woorint cable forces and large surging, swaying or heaving thotions, aepenuing upon initial cable tension, wave period and vessel heading. If the characteristics of the woves in a certain location were known, it should be possible to use the curves rresented in this report to predict the dangerous conditions.

In regard to roll-dariping devices, it wes found that the bilge keels decreased the periodic roll angle considerably (especially for the snort period waves); however, when bilge keels were used, a "dynamic list" was developed.

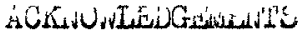

The authors wish to express their appreciation to the Cdifornia Research Corporation for making this study possible, and to Drs. G. 1.

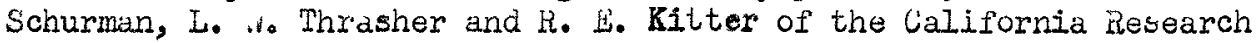
Corporation for their suggestions and encourdgenent during the study; to R. C. wiley for his workmanship in construction of the model and force neters; to $A$. I. Arnold for his help in conducting the experiments; to Dr. $H$. $j_{0}$ Clough for his comments on the model laws, the theoretical consideration and the design of the force weters; to John williams, Jaak Kukk, S. K. Wihara, it. Bennett and Stephen thisenand for helping to arldlyze the datid; and to ki in. Iincoln for preparing the manuscript.

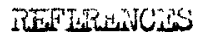

Eeebe, K. E. (1955). Wooring forces caused by wave action on floatins structures: Proc. First Conference on Ships and vives, Council on dave Research, ungineerins Foundatzon, and Society of ivaval irchitects and biarine Engineers, pp. 474-488.

Eeebe, K. E. (1955). A prelininary study of forces in ship moorines Jue to wave action: Institute of lingineering lesearch, University of California, Berkeley, California, Tech. Report Series 91, Issue 1, 9 pages.

Beebe, K. E. (1956). Wooring cable force meter for models: Froc. First Conference on Coastal ingineering Instruments, Councll on wave Research, The kngineering Foundation, Berkeley, California, pp. $134-143$.

Carr, wCGraw and Shapiro (1953). Investigation of ship mooring forces: findl report: Carr, bcGraw and shapiro, wechanicol and Hlectrical Iingineers, Sierra kladre, California, Report to Euredu of Yards and Docks, Lept. of the $\mathrm{Navy}$, Contract $\mathrm{NU}_{\mathrm{U}}-27482,19$ pages. 


\section{COASTAL ENGINEERING}

Froude, W. (1861). On the rolling of ships: Trans. Institution of Naval Architects, vol. 2, pp. 180-227.

Fuchs, R. A. (1955). A linear theory of ship motion in irregular waves: Proc. First Conference on Ships and Naves, Council on wave Research, The fingineering Foundation, and Society of Naval Architects and Marine Engineers, pp. 186-193.

Grim, Otto (1953). Rolling, stability and safety in a seaway: Forschun: shefte fur Schiffbautechnik, vol. 1, 1952, a translation and summar. of the original paper by E. V. Lewis, Experimental Towing Tank, Stevens Inst. of Technology, Note Ho. 234, 12 pp.

Haskind, M. D. (1946). The hydrodynamical theory of the oscillations of a ship in weves: Prikladnaya latematika $i$ kiekhanika (translation b, the Society of Naval Architects and Marine Eingineers).

Havelock, T. H. (1940). The pressure of water waves upon a fixed obstac Proc. Royal Society of London, Series A, vol. 175, pp. 409-421.

Kent, J. I. (1941). Experiments in rough water with a single screw ship model: Trans. The Inst. of ingineers and Shipbuilders in Scotland, Paper No. 1017, pp. 212-252.

Kriloff, Captain A. (1898). A general theory of the oscillations of a ship on waves: Trans. Inst. of Naval Architects, vol. 40, pp. $135-190$.

O'Brien, J. T. (1955). Forces on moored ships due to wave action: Pror First Conference on Ships and Waves, Council on Wave Research, The Engineering Foundation, and Society of Naval Architects and Marine Engineers, pp. 455-473.

Rossell, H. E., and Chapman, L. B. (1939). Princlples of Naval Architecture, vol. II: The Society of Naval Architects and Larine Engi neers, New York, New York, 242 pages.

Sibul, 0. J. (1955). Laboratory studied of the motions of freely floating bodies in non-uniform and uniform long crested waves: $\mathrm{Pr}$ First Conference on Ships and Waves, Council on wave Research, The Engineering Foundation, and Society of Naval Architects and Marine Engineers, pp. 366-396.

St. Denis, H., and Pierson, Jr., W. J. (1955). On some recent developments in the theory of ship motions: Proc. First Conference on Ships and Waves, Council on Wave Hesearch, The ingineering Founda. tion, and Society of Naval Architects and Warine Engineers, pp. 160-184.

Timoshenko, S. (1937). Vibration problems in engineering (2nd edition 2nd printing): 0 . Van Nostrand Co., Inc., 470 pages. 


\section{MODEL STUDIES OF THE DYNAMICS OF AN LSM MOORED IN WAVES}

Vieinblum, G. P. (1955). Progress of theoretical investigations of ship motions in a seaway: Proc. First Conference on Ships and Waves, Council on ivave Research, The Engineering Foundation, and Society of Naval Architects and Marine Engineers, pp. 129-159.

Weinblum, G. P., and St. Denis, M. (1950). On the motions of ships at sea: Trans. The Society of Naval Architects and Narine Engineers, vol. $58, \mathrm{pp} .184-248$.

Wiegel, R. L. (1949). An analysis of data from wave recorders on the Pacific Coast of the United States: Trans. American Geophysical Union, vol. 30 , no. 5, pp. 700-704.

itiegel, R. L., Patrick, D. A., and Kimberley, H. I. (1954). Wave, longshore current and beach profile records for Santa inargarita River beach, Oceanside, California, 1949: Trans. Anerican Geophysical Union, vol. 35, no. 6, pp. 887-896.

Williams, A. J. (1953). An investigation into the motions of ships at sea: Trans. Inst. of Naval Architects, vol. 95, pp. 70-84.

Hilson, B. W. (1950). Ship response to range action in harbor basins: Proc. A.S.C.5。, vol. 76, Separate ivo. 41, 29 pages.

wilson, B. W., and Abramson, H. N. (1955). A further analysis of the longitudinal response of moored vessels to sea oscillations: The $A$ \& if College of Texas, Texas A \& W Research Foundation, A \& M Project 24, Reference 55-16T, 13 pages. 